\title{
Alternative Therapeutic Options to Antibiotics for the Treatment of Urinary Tract Infections
}

\author{
Paul Loubet ${ }^{1}$, Jérémy Ranfaing ${ }^{2}$, Aurélien Dinh ${ }^{3}$, Catherine Dunyach-Remy ${ }^{2}$, \\ Louis Bernard $^{4,5}$, Franck Bruyère ${ }^{4,6}$, Jean-Philippe Lavigne ${ }^{2 *}$ and Albert Sotto ${ }^{1}$ \\ 1 VBMI, INSERM U1047, Université de Montpellier, Service des Maladies Infectieuses et Tropicales, CHU Nimes, Nimes, \\ France, ${ }^{2}$ VBMI, INSERM U1047, Université de Montpellier, Service de Microbiologie et Hygiène Hospitalière, CHU Nîmes, \\ Nimes, France, ${ }^{3}$ Service des Maladies Infectieuses, AP-HP Raymond-Poincaré, Garches, France, ${ }^{4}$ PRES Centre Val \\ de Loire, Université François Rabelais de Tours, Tours, France, ${ }^{5}$ Service des Maladies Infectieuses, CHU Tours, Tours, \\ France, ${ }^{6}$ Service d'Urologie, CHU Tours, Tours, France
}

OPEN ACCESS

Edited by:

Ilana L. B. C. Camargo,

University of São Paulo, Brazil

Reviewed by:

Nina Chanishvili,

George Eliava Institute

of Bacteriophage, Microbiology and Virology, Georgia

Jason John Paxman,

La Trobe University, Australia

Saeid Bouzari,

Pasteur Institute of Iran (PII), Iran

*Correspondence:

Jean-Philippe Lavigne

jean.philippe.lavigne@chu-nimes.fr

Specialty section:

This article was submitted to Antimicrobials, Resistance

and Chemotherapy,

a section of the journa

Frontiers in Microbiology

Received: 27 November 2019 Accepted: 10 June 2020

Published: 03 July 2020

Citation:

Loubet P, Ranfaing J, Dinh A, Dunyach-Remy $C$, Bernard $L$, Bruyère $F$, Lavigne $J$ - $P$ and Sotto $A$

(2020) Alternative Therapeutic

Options to Antibiotics

for the Treatment of Urinary Tract Infections. Front. Microbiol. 11:1509.

doi: 10.3389/fmicb.2020.01509
Urinary tract infections (UTIs) mainly caused by Uropathogenic Escherichia coli (UPEC), are common bacterial infections. Many individuals suffer from chronically recurring UTIs, sometimes requiring long-term prophylactic antibiotic regimens. The global emergence of multi-drug resistant uropathogens in the last decade underlines the need for alternative non-antibiotic therapeutic and preventative strategies against UTIs. The research on non-antibiotic therapeutic options in UTIs has focused on the following phases of the pathogenesis: colonization, adherence of pathogens to uroepithelial cell receptors and invasion. In this review, we discuss vaccines, small compounds, nutraceuticals, immunomodulating agents, probiotics and bacteriophages, highlighting the challenges each of these approaches face. Most of these treatments show interesting but only preliminary results. Lactobacillus-containing products and cranberry products in conjunction with propolis have shown the most robust results to date and appear to be the most promising new alternative to currently used antibiotics. Larger efficacy clinical trials as well as studies on the interplay between non-antibiotic therapies, uropathogens and the host immune system are warranted.

Keywords: urinary tract infection, alternative therapeutics, vaccines, nutraceuticals, immunomodulating agents, probiotics, cranberry, bacteriophages

\section{INTRODUCTION}

Urinary Tract Infections (UTIs) are frequent bacterial infections (Silverman et al., 2013) especially in women, estimated to affect more than one in every two women at least once in her lifetime (Foxman, 2014; McLellan and Hunstad, 2016). Uropathogenic Escherichia coli (UPEC) is the main pathogen isolated from patients with UTIs (>85\%) (Flores-Meireles et al., 2015), while other Gram-negative rods (e.g., Proteus mirabilis, Klebsiella pneumoniae) and Gram-positive cocci (e.g., Staphylococcus saprophyticus, Enterococcus faecalis) are responsible for the remaining cases (Flores-Meireles et al., 2015). UTI recurrence is defined by the occurrence of more than two episodes in 6 months, or three in 12 months (Professionals, 2019). The annual incidence of UTI in women is estimated to be 30 per 1000 subjects (Laupland et al., 2007), with approximately 
20-40\% experiencing recurrence within 6-12 months (Ikähelmo et al., 1996; Foxman, 2014). The epidemiology of UTI changes significantly in the healthcare environment. Urethral catheterization is strongly associated with UTI, and the risk of infection increases with the length of catheterization (Suetens et al., 2018). Catheter-associated UTI (CAUTI) is the most common nosocomial infection (Suetens et al., 2018). CAUTI affects both sexes, with long-term urinary catheterization of both men and women almost invariably leading to detection of bacteria in the urine (bacteriuria). Long-term catheterization carries a daily risk of 3-7\% for the development of symptomatic CAUTI (Saint et al., 2009).

The urinary tract is normally sterile, with the exception of the flora of the distal urethra which is diverse and reflects both the digestive flora, the cutaneous flora and genital flora (Lactobacilli in women). There are several physiological mechanisms to prevent the host from the development of an ascending infection. First, the urethra itself, which is an obstacle to the intravesical inoculation; second, the physicochemical characteristics of normal urine (osmolarity, $\mathrm{pH}$, organic acid content) that makes growth of most of the bacteria colonizing the urethra difficult; third urination that eliminates most of the bacterial population; fourth the presence in the urine of glycoproteins and oligosaccharides acting as soluble receptors to capture bacteria and enhance their clearance. Finally, in case of bacterial colonization, three factors contribute to avoid the invasion of the mucous membrane (Sobel, 1997): (i) the presence of inhibitors of bacterial adhesion to the surface of urothelial cells (Tamm-Horsfall protein, mucopolysaccharides); (ii) the existence of a local bactericidal effect (independent of inflammatory response or immune response); (iii) a process of exfoliation of the infected urothelial cells. The occurrence of UTI implies either a flaw in these defense mechanisms or the development in the urethral flora of a virulent bacteria, termed uropathogenic. Only a minority of E. coli strains, are endowed with uropathogenicity by the production of one or more adhesins (fimbriae): (i) type 1 allowing low urinary tract colonization, (ii) type $\mathrm{P}$ inducing pyelonephritis by modification of ureteral peristalsis in binding to glomerulus and endothelial cells of vessel walls helping E. coli to cross the epithelial barrier to enter the bloodstream and causing hemagglutination of erythrocytes and by decreasing the renal filtrate flow due to the formation of dense bacterial communities within the tubular lumen (Roberts, 1991; Melican et al., 2011), and (iii) non-fimbrial adhesins such as UpaB that facilitate E. coli adherence to extracellular matrix proteins and colonization of the urinary tract (Paxman et al., 2019). An increased adherence of $E$. coli to uroepithelial cells is observed in patients with recurrent UTIs compared to healthy controls (Schaeffer et al., 1981). Moreover, it has been demonstrated that UPEC can invade and replicate within the bladder cells to form intracellular bacterial communities (Mulvey et al., 2001), which can be frequently found in urothelial cells in women with symptomatic UTIs (Rosen et al., 2007) and may act as a source of recurrence in women with same-strain recurrent UTIs (Beerepoot et al., 2012a). Finally, biofilm formation is a critical aspect of CAUTI (Soto et al., 2006; Beerepoot et al., 2012a). Mechanisms of recurrence in UTIs are not fully characterized.
Besides pathogen virulence factors, an impaired mucosal immune response (with urinary IgA involved in the UPEC clearance from the bladder mucosa) of the urogenital tract may have a role in the host-pathogen process (Ingersoll and Albert, 2013; Abraham and Miao, 2015).

Long-term low dose antibiotic use is currently the keystone of the preventive treatment for UTI recurrence. Indeed, prophylactic antibiotics have been shown to decrease UTI recurrence by $85 \%$ compared to patients with placebo (relative risk (RR) 0.15 , 95\% confidence interval (95\%CI) 0.08 to 0.28 ) (Albert et al., 2004). Moreover, with regard to urinary tract conditions such as neurogenic bladder, it has been suggested that weekly cycling of antibiotics could be the most optimal preventative strategy (Salomon et al., 2006; Dinh et al., 2019). Indeed, this original strategy seems effective with only a limited ecological effect on native gut microbiota according to long-term follow-up (Poirier et al., 2015). However, prolonged antibiotic use often results in the emergence of multidrug-resistant organisms (Beerepoot et al., 2012b) and increases the cost of care. Consequently, the development of new therapeutic options to prevent and treat UTIs, and most particularly recurrent UTIs, are of interest.

This review aims to describe all the existing non-antibiotic treatment options in UTI (Table $\mathbf{1}$ and Figure 1).

\section{VACCINES}

Vaccines have been studied to prevent recurrent UTI in the aim not to kill infectious pathogens but to protect the host against infection by priming the immune response to uropathogens. Different vaccine strategies have considered the use of both surface antigen or inactivated whole bacterium, from uropathogens, to generate protective antibodies as a preventive strategy for recurrent UTIs. An ideal vaccine will target factors critical for establishment of bladder colonization (O’Brien et al., 2016). In this way, vaccines containing $\mathrm{O}$ antigens (important virulence factors that are targets of both the innate and adaptive immune systems), fimbrial subunits (responsible for the attachment to host cells, the first step of UTI), $\alpha$-hemolysin (a membrane-active protein exotoxin leading to serious tissue damage), siderophores and a variety of outer membrane siderophore receptors (allowing the sequestration of iron, the main source of bacterial growth) have been developed.

\section{Current Vaccine Solutions}

There are currently four available vaccines with established results from randomized control trials (RCT): Uro-Vaxom ${ }^{\circledR}$, Urovac $^{\circledR}$, ExPEC4V and Uromune ${ }^{\circledR}$ (Aziminia et al., 2019).

- Uro-Vaxom ${ }^{\circledR}$, also known as $\mathrm{OM}-89$, is comprised of bacterial extracts from 18 UPEC strains that mediated its effect by the ability of bacterial component pathogenassociated molecular patterns to non-specifically stimulate cells of the innate immune systems (Huber et al., 2000). This effect was shown in mouse models inducing an immunological defense response within the bladder. 
TABLE 1 | Non-antibiotic therapeutic options for the treatment of urinary tract infections.

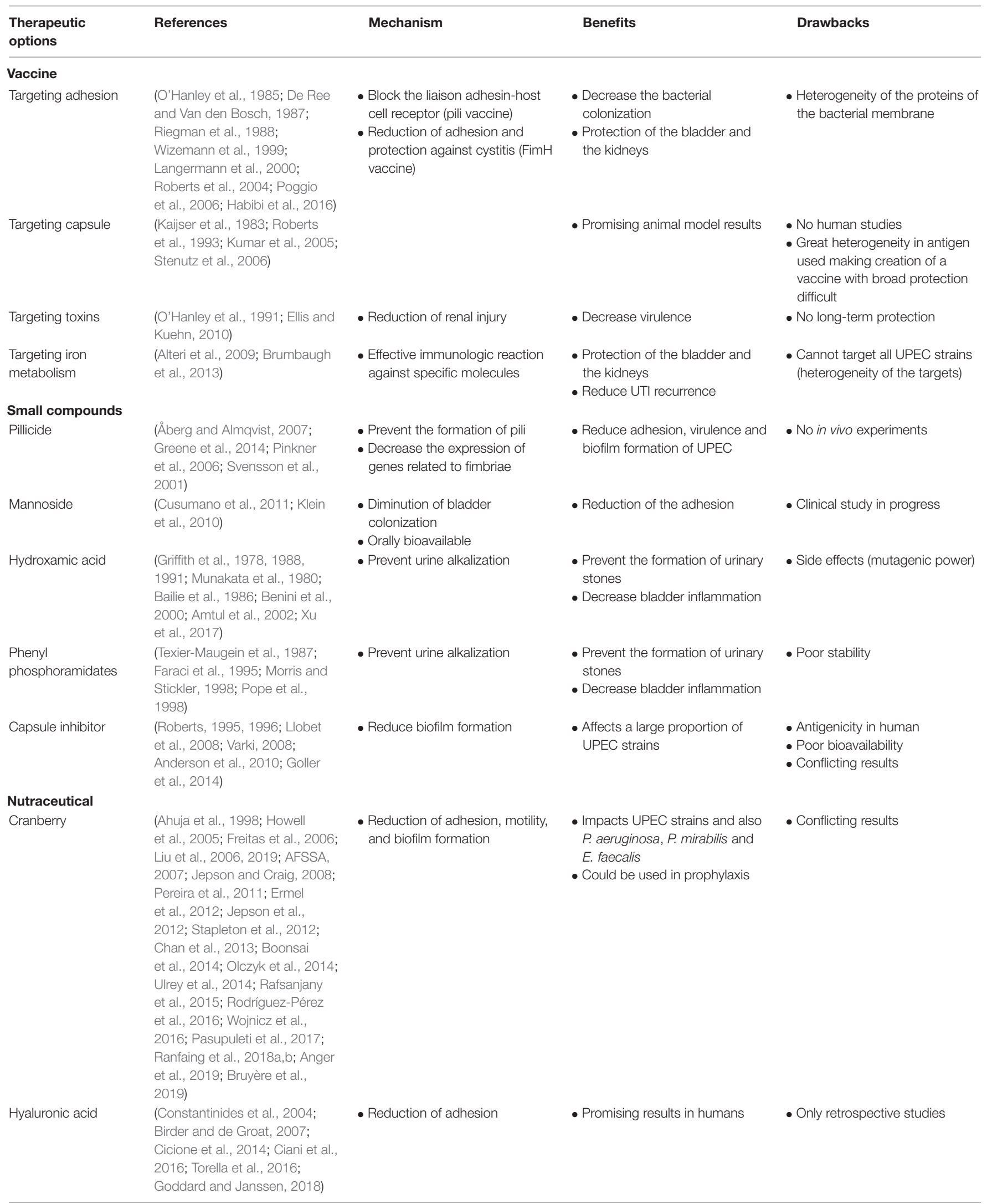


TABLE 1 | Continued

\begin{tabular}{|c|c|c|c|c|}
\hline $\begin{array}{l}\text { Therapeutic } \\
\text { options }\end{array}$ & References & Mechanism & Benefits & Drawbacks \\
\hline D-mannose & $\begin{array}{l}\text { (Hills et al., 2001; Klein et al., } \\
\text { 2010; Cusumano et al., 2011; } \\
\text { Kranjčec et al., 2014; Domenici } \\
\text { et al., 2016) }\end{array}$ & - Reduction of adhesion & $\begin{array}{l}\text { - Fast effect after oral } \\
\text { administration }\end{array}$ & - Conflicting results \\
\hline Galabiose & $\begin{array}{l}\text { (Strömberg et al., 1990; Sung } \\
\text { et al., 2001; Larsson et al., } \\
\text { 2003) }\end{array}$ & - Reduction of adhesion & - Diminution of kidney infections & - Not enough in vivo results \\
\hline $\begin{array}{l}\text { Chinese Medical } \\
\text { Herb and other } \\
\text { plants }\end{array}$ & $\begin{array}{l}\text { (Banu and Kumar, 2009; Gu } \\
\text { et al., 2011; Issac Abraham } \\
\text { et al., 2011; Tong et al., 2011; } \\
\text { Zhao et al., 2011; Flower et al., } \\
\text { 2015; Meng et al., 2015; Hou } \\
\text { and Wang, 2016; Pu et al., } \\
\text { 2016; Sharifi-Rad et al., 2016; } \\
\text { Mazarei et al., 2017; Jaiswal } \\
\text { et al., 2018; Mickymaray and Al } \\
\text { Aboody, 2019) }\end{array}$ & - Reduction of adhesion & - Reduction of UTI recurrences & $\begin{array}{l}\text { - Small size studies } \\
\text { - Little safety data }\end{array}$ \\
\hline \multicolumn{5}{|c|}{ Immunomodulant agents } \\
\hline COX-2 inhibitor & $\begin{array}{l}\text { (Bleidorn et al., 2010; Hannan } \\
\text { et al., 2014; Moore et al., 2019) }\end{array}$ & $\begin{array}{l}\text { - Reduction of inflammation } \\
\text { linked to cystitis }\end{array}$ & $\begin{array}{l}\text { - Substantial reduction of UTI } \\
\text { recurrences }\end{array}$ & $\begin{array}{l}\text { - No significant results in clinical } \\
\text { trials }\end{array}$ \\
\hline Green Tea Extract & $\begin{array}{l}\text { (Hoshino et al., 1999; Arakawa } \\
\text { et al., 2004; Cooper et al., } \\
\text { 2005a,b; Reygaert and Jusufi, } \\
\text { 2013; Bae et al., 2015) }\end{array}$ & - Reduction of inflammation & - Reduction of UTI recurrences & $\begin{array}{l}\text { - Mechanisms of action unclear } \\
\text { - Not proved in humans }\end{array}$ \\
\hline \multicolumn{5}{|l|}{ Probiotics } \\
\hline Vaginal lactobacilli & $\begin{array}{l}\text { (Isolauri et al., 2001; Galdeano } \\
\text { and Perdigón, 2006; De Vuyst } \\
\text { and Leroy, 2007; Cribby et al., } \\
\text { 2008; Cadieux et al., 2009; } \\
\text { Riaz et al., 2010; Hardy et al., } \\
\text { 2013; Kemgang et al., 2014; Di } \\
\text { Cerbo et al., 2016; Chikindas } \\
\text { et al., 2018; Ng et al., 2018; } \\
\text { Koradia et al., 2019) }\end{array}$ & $\begin{array}{l}\text { - Competition, reduction of } \\
\text { adhesion and virulence }\end{array}$ & $\begin{array}{l}\text { - Natural production of } \\
\text { antimicrobial compounds } \\
\text { - No known side effects }\end{array}$ & - Not enough in vivo results \\
\hline E. coli 83972 & $\begin{array}{l}\text { (Hull et al., 2000; Darouiche } \\
\text { et al., 2001, 2005; Dashiff et al., } \\
\text { 2011; Roos et al., 2006; } \\
\text { Trautner et al., 2007; Prasad } \\
\text { et al., 2009; Sundén et al., } \\
\text { 2010) }\end{array}$ & $\begin{array}{l}\text { - Colonization of the bladder by } \\
\text { avirulent strain }\end{array}$ & - Reduction of UPEC colonization & $\begin{array}{l}\text { - Not enough inclusions in clinical } \\
\text { studies }\end{array}$ \\
\hline Predatory bacteria & $\begin{array}{l}\text { (Stolp and Starr, 1963; Kadouri } \\
\text { and O'Toole, 2005; Sockett, } \\
\text { 2009; Dashiff et al., 2011; } \\
\text { Shatzkes et al., 2015; Gupta } \\
\text { et al., 2016) }\end{array}$ & $\begin{array}{l}\text { - Decrease of bacterial number } \\
\text { and biofilm formation }\end{array}$ & $\begin{array}{l}\text { - Efficient against Gram-negative } \\
\text { bacteria }\end{array}$ & - Not yet tested to treat UTIs \\
\hline Bacteriophages & $\begin{array}{l}\text { (Dufour et al., 2016; Sybesma } \\
\text { et al., 2016; Leitner et al., 2017; } \\
\text { Ferry et al., 2018; Ujmajuridze } \\
\text { et al., 2018; Jault et al., 2019; } \\
\text { Kuipers et al., 2019) }\end{array}$ & - Direct bacteria killing & $\begin{array}{l}\text { - Interesting animal models and } \\
\text { human case reports. }\end{array}$ & $\begin{array}{l}\text { - More human studies are } \\
\text { required }\end{array}$ \\
\hline
\end{tabular}

However, its use in human trials has shown conflicting results. Four placebo controlled studies (Tammen, 1990; Schulman et al., 1993; Magasi et al., 1994; Bauer et al., 2005) showed that taking one Uro-Vaxom ${ }^{\circledR}$ tablet daily for 3 months significantly reduced the number of UTIs in the treatment group, with a $\mathrm{RR}=0.61(95 \% \mathrm{CI}$ 0.48-0.78) of developing a UTI in the treatment group during an observation ranging from 3 to 12 months.
However, a recent multicenter double-blind control trial of 451 patients showed no significant difference in UTI rates between Uro-Vaxom ${ }^{\circledR}$ and the placebo (Wagenlehner et al., 2015).

- Urovac ${ }^{\circledR}$ is a mucosal vaccine in the form of a vaginal suppository containing 10 different strains of heatinactivated uropathogenic bacteria (six serotypes of $E$. coli strains, P. vulgaris, Morganella morganii, E. faecalis and 


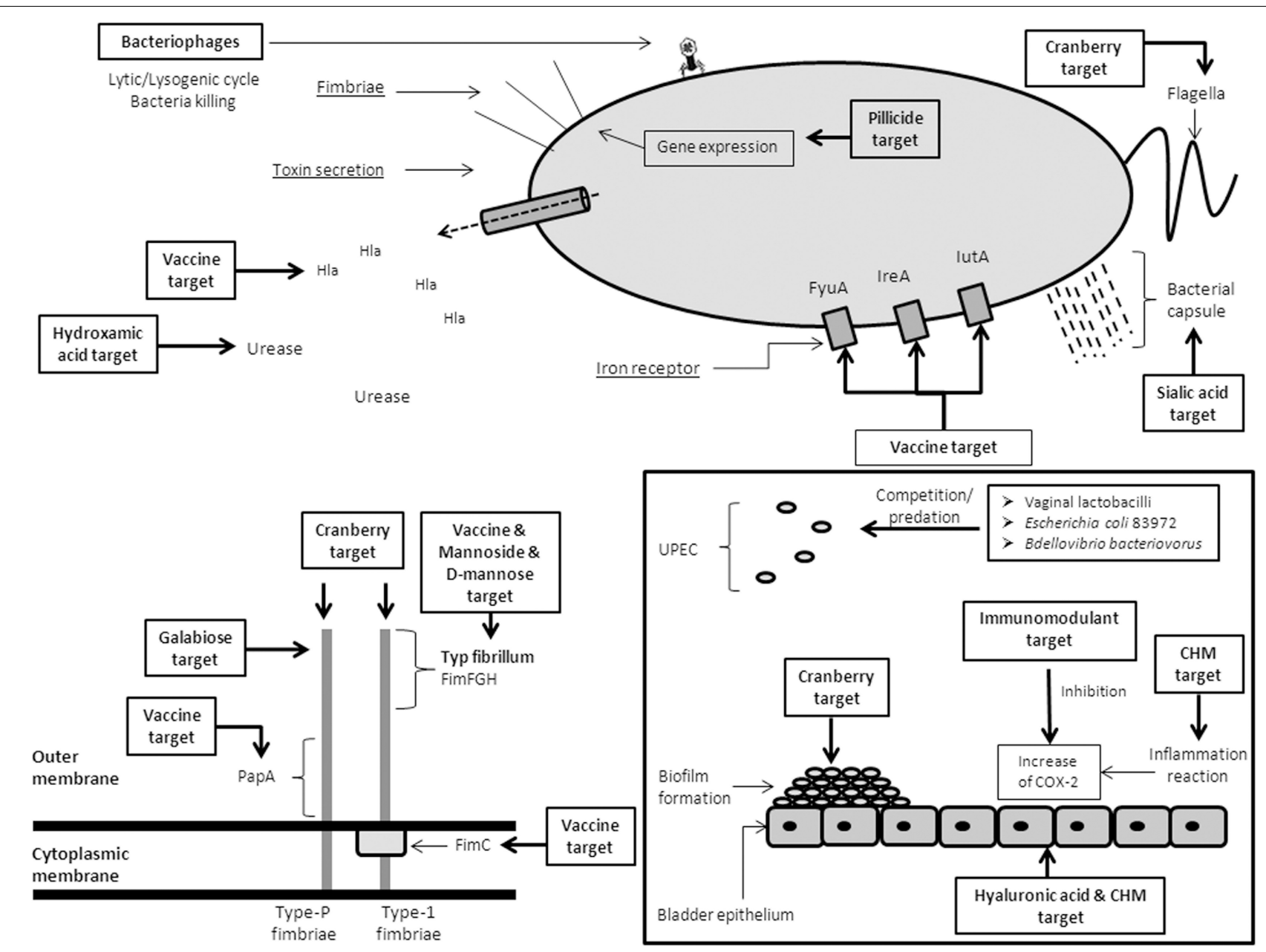

FIGURE 1 | Recapitulative scheme of the alternative therapeutic options against UPEC. CHM: Chinese Herbal Medicine.

K. pneumoniae) (Yang and Foley, 2019). The aim of this vaccine preparation was to incorporate a broader range of commonly implicated uropathogens and thus provide broad protection. Overall, Urovac ${ }^{\circledR}$ has been shown to reduce the risk of recurrence (RR 0.75 , 95\% CI 0.63-0.89) (Uehling et al., 1997, 2003; Hopkins et al., 2007). This effect was more pronounced in the group that received a follow-up booster vaccination (Aziminia et al., 2019).

- ExPEC4V is composed of $\mathrm{O}$-antigens of four E. coli serotypes (O1A, O2, O6A, and O25B) delivered as a single intra-muscular injection. These serotypes are a key immune evasion strategy used by the bacterium. This vaccine has shown good safety and immunogenicity in several phase 1 and 2 trials (Hopkins et al., 2007; Huttner et al., 2017; Huttner and Gambillara, 2018; Frenck et al., 2019).

- Uromune ${ }^{\circledR}$ is a new sublingual vaccine composed of inactivated E. coli, K. pneumoniae, Proteus vulgaris and E. faecalis. This vaccine has been evaluated in three large retrospective Spanish studies and showed a $70-90 \%$ reduction of recurrence when compared to antibiotic prophylaxis (Lorenzo-Gómez et al., 2013, 2015). A prospective observational study showed that 59 out of 75 women $(78 \%)$ which received 3 months of Uromune ${ }^{\circledR}$ treatment as a sub-lingual spray once a day, had no new UTIs during both the treatment and the one year of followup period (Yang and Foley, 2018). Another recent lager prospective study showed that $65 \%$ of 784 women had 0 or 1 UTI after 6 months of daily sub-lingual administration of Uromune $^{\circledR}$ (Ramirez Sevilla et al., 2019).

This interesting result should be confirmed in a larger study with a control group. It has to be noted that the need for a 3-month daily administration raises questions on the immunogenicity and the expected compliance to this treatment. One international multicenter phase III RCT is currently underway.

A recent meta-analysis noted that the use of vaccines appeared to reduce UTI recurrence compared to placebo. However, the heterogeneity amongst studies renders interpretation and recommendation for routine clinical use difficult at present (Prattley et al., 2020). Further randomized controlled trials are 
warranted to assess the efficiency and the safety of the existing vaccines against UTIs.

\section{New Candidates}

Several bacterial virulence factors involved in UTI are promising vaccine targets.

\section{Vaccines Targeting Adhesion}

Bacterial adhesion to urothelium represents a crucial step in the pathogenesis of UTIs. It permits bacteria to resist mechanical elimination by the flow of urine and bladder and increases persistence of $E$. coli. One large family of adhesive organelles are pili assembled by the chaperone-usher pathway (CUP) pili. These pili are critical virulence factors in a wide range of pathogenic bacteria, including E. coli. CUP pili mediate adhesion to host and environmental surfaces, facilitate invasion of host tissues, and promote interaction of bacteria with each other to form biofilms (Sauer et al., 2004). The most studied of the CUP pili are the Type $1, \mathrm{P}$, and $\mathrm{S}$ pili, present in UPEC and allowing the colonization of mucosal surfaces. They promote both irreversible bacterial attachment and invasion of uroepithelial cell membrane within the bladder. Interactions mediated by these adhesins can stimulate a number of host responses that can directly influence the outcome of a UTI (Mulvey, 2002). They are thus promising vaccine candidates because of the importance of this adhesion. The potential exists to develop antibodies that block the adhesin-host cell receptor interaction and thus decrease bacterial colonization (Wizemann et al., 1999).

FimH is a major determinant of the adhesive subunit of Type 1 fimbriae, which has high tropism for urinary tract receptors. It binds to mono-mannose. Lack of this compound on renal epithelia has suggested a limited role in pyelonephritis. It has been targeted as a good candidate for a vaccine because of its critical role in cystitis pathogenesis (Figure 1). A FimCH vaccine protected cynomolgus monkeys from cystitis (Langermann et al., 2000). Another study on mice with an intranasal and intramuscular administration also showed a protection against cystitis, but the intranasal method produced a stronger immune response (Poggio et al., 2006). In a more recent study, a recombinant protein MrpH.FimH (consisting of a combination between two adhesins, FimH from UPEC and MprH from P. mirabilis) was injected with a transurethral instillation and the authors demonstrated a high immune response and a protection against E. coli and P. mirabilis (Habibi et al., 2016).

By comparison the Type $\mathrm{P}$ pilus is more involved in pyelonephritis due to the presence of globoseries glycosphingolipids (the receptor of this pilus) in kidney. This P fimbria helps to cross the epithelial barrier to enter the bloodstream and can cause hemagglutination of erythrocytes (Riegman et al., 1988). Approximatively 1,000 of subunits form a P fimbria. Among them the major constituent is the protein subunit PapA, and minor subunits are PapD, PapE, PapF, and PapG. So subunit vaccines based on this pilus have been developed to block renal colonization. Attempts on using the major subunit PapA as a vaccine, although initially favorable in mice (O'Hanley et al., 1985), failed due to the poor generation of protective antibodies most probably due to natural variation in the PapA pilus subunit (Figure 1; De Ree and Van den Bosch, 1987). A new vaccine based on purified PapDG protein demonstrated a good efficiency to prevent colonization of kidney on cynomolgus monkeys (Roberts et al., 2004).

\section{Vaccines Targeting Capsule}

The main role of a capsule is to cover and protect E. coli from the host immune system. It provides protection against engulfment and complement-mediated bactericidal effect in the host (Johnson, 1991). Based on this implication in virulence strategy, capsules represent a promising vaccine target. In this way, conjugate UTI vaccines against UPEC capsule and lipopolysaccharide (LPS) components have shown protection in animal models after same-strain challenge. In early studies, intraperitoneal, subcutaneous or bladder injection of O-antigen from E. coli of different serotypes (O6, O8 and K13) protected rats and rhesus monkeys from pyelonephritis (Kaijser et al., 1983; Roberts et al., 1993; Kumar et al., 2005). A considerable challenge in formulating a vaccine targeting capsule or O-antigen, the most exposed component of LPS, is the great heterogeneity of serotypes among E. coli isolates. Indeed, six different $\mathrm{O}$ serotypes account for only 75\% of UPEC isolates (Stenutz et al., 2006), making the formulation of a broadly protective conjugate vaccine impractical. Furthermore, some capsule serotypes, such as K1 and $\mathrm{K} 5$, are thought to evade the host immune response by molecular mimicry, potentially making them poor vaccine candidates. No studies on these vaccines have been conducted in humans yet.

\section{Vaccines Targeting Toxins}

Several toxins secreted by UPEC play a consequential role as virulence factors in UTI. They have the ability to alter the host cell signaling cascade and modulate inflammatory responses. They also contribute to the stimulation of the host cell death and the ability to access deeper tissues. Many toxins have been reported including $\alpha$-hemolysin (HlyA) or cytotoxic necrotizing factor 1 (CNF1). $\alpha$-hemolysin is a pore-forming toxin, it can lyse erythrocytes, and induces the apoptosis of target host cells promoting the exfoliation of bladder epithelial cells (Johnson, 1991). CNF1 stimulates actin stress fiber formation and membrane ruffle formation resulting in the entry of $E$. coli into the cells. This protein interferes with polymorphonuclear phagocytosis and provokes apoptotic death of bladder epithelial cells (Asadi Karam et al., 2019). Following their importance in virulence, the toxins produced by UPEC have been used to develop vaccines to protect the bladder and kidney during a UTI. However, as they are secreted and thus removed from the bacteria, they do not make ideal vaccine candidates. Indeed, a purified $\alpha$-hemolysin toxoid vaccine prevented renal injury, but not colonization, in mice after challenge with a hemolytic UPEC strain (Figure 1; O'Hanley et al., 1991). Of note, rather than being secreted as "naked" proteins, $\alpha$-hemolysin and CNF1 are associated with outer membrane vesicles (OMVs), which bleb from the surface of Gram-negative bacteria during all stages of growth (Ellis and Kuehn, 2010). OMVs also contain adhesins, enzymes, and non-protein antigens like LPS. OMVs are intriguing vaccine candidates, and because they contain LPS 
and other pro-inflammatory virulence factors, they should not require adjuvants to stimulate the immune system. However, no UPEC OMV vaccines have yet been tested.

\section{Vaccines Targeting Iron Metabolism}

The acquisition of iron is crucial for bacteria life and E. coli uses iron for transporting and storing oxygen, DNA synthesis, electron transport and metabolism peroxides. However, the amount of iron availability is reduced in host. In response, E. coli produces siderophores, molecules that mediate iron uptake. Four siderophore systems have been identified such as yersiniabatin, aerobactin, enterobacterin, and salmochelin (Johnson, 1991).

Some studies have targeted siderophore, heme receptors and other functional molecules involved in iron acquisition. In one study, the authors tested six iron receptors and found that the antibodies against the yersiniabactin receptor, FyuA, conferred kidney protection in mice (Brumbaugh et al., 2013). In another mouse model, instead of targeting iron receptors, the same authors targeted molecules involved in iron metabolism. Of the six candidates, two conferred a protection to the bladder (IreA and IutA) and one protected the kidneys (Hma) after an intranasal immunization (Alteri et al., 2009).

\section{SMALL COMPOUNDS}

In the current setting small compounds are low molecular weight molecules that are typically bacterial substrates or products or mimics thereof. They can act as inhibitors by binding active sites and substrate binding sites of proteins involved in pathogenicity and so impact bacterial infections.

\section{Small Compounds Targeting Adhesion}

As previously noted, one of the critical mechanisms for the pathogenesis of the uropathogenic bacteria is its adhesion to uroepithelium (Beerepoot and Geerlings, 2016), due to fimbriae (specially the Type 1 and the P-fimbriae), playing a role in both cystitis and pyelonephritis (Beerepoot and Geerlings, 2016; Muenzner et al., 2016). The very conserved structure of the adhesive organelles makes them good candidates to develop antibacterial agents (Piatek et al., 2013). The small molecules targeting adhesion can be classified into two categories: those inhibiting the capacity of adhesion of the fimbriae, and those targeting fimbriae assembly.

\section{Pilicide}

The main action of these molecules is to prevent the formation of UPEC pili by decreasing the levels of Type 1 and P piliation (Åberg and Almqvist, 2007). Pilicides are small molecules which have a ring-fused 2-pyridone backbone. Some pilicides act directly on pili assembly chaperones, through adhering to their hydrophobic substrate binding sites (Svensson et al., 2001; Pinkner et al., 2006). Others interfere with the transcription of pili genes and some cases genes involved in flagella biogenesis such as the pilicide ec240, the most potent inhibitor of Type 1 piliation and of type 1 pilus-dependent biofilm formation to date (Greene et al., 2014).
In vitro studies testing the potential of pilicides have shown promising results. These compounds decreased (i) the adhesion of UPEC strains on cells by a strong reduction $(70-80 \%)$ of fimbriae density (Piatek et al., 2013), and (ii) the ability to form Type 1 pilus dependent biofilms (Pinkner et al., 2006). In a mouse study, the pilicide had a strong impact on adhesion and biofilm formation and also reduced the virulence in vivo. It is also interesting to note that it reduced the biofilm formation on abiotic surface (Cegelski et al., 2010).

To develop this compound into a therapeutic, further studies are needed to assess its pharmacokinetics and pharmacodynamics and to determine the concentration at which it accumulates in the bladder or other potential sites of infection.

\section{Small Compounds Targeting Urease}

Urease, an enzyme which catalyzes the hydrolysis of urea, is crucial in the pathogenesis of several uropathogenic bacteria such as P. mirabilis, Klebsiella sp., Pseudomonas sp. and Staphylococcus sp. (Mobley and Hausinger, 1989). This enzyme leads to the alkalinization of the urine and the production of struvite and carbonate apatite that make up the major component of urinary stones (Burne and Chen, 2000). These conditions lead to the inflammation of the urogenital epithelia thus increasing the risk of catheter-associated biofilm formation that may contribute to pyelonephritis (Musher et al., 1975; Jacobsen et al., 2008), mainly due to both bacterial and host cysteine protease (Xu et al., 2017).

The most studied inhibitors of urease are hydroxamic acids (Amtul et al., 2002; Figure 1). These molecules have a high inhibitory activity against urease, by bonding to the two nickel ions in the urease active site (Benini et al., 2000). Initially, these molecules were used to treat UTIs by preventing urine alkalization (Griffith et al., 1978, 1988). However, because of the growing evidence of side effects such as mutagenic power, they were progressively phased out (Munakata et al., 1980; Bailie et al., 1986; Griffith et al., 1991).

Through similarly interacting with nickel ions in the urease active site, the phenyl phosphoramidates were found to have the highest inhibitory activity (Faraci et al., 1995). Studies testing these molecules in an in vitro model (Morris and Stickler, 1998) and in a rat model (Texier-Maugein et al., 1987) found promising results. Since then, no in vivo studies or clinical trials have been developed, probably due to the poor hydrolytic stability of these molecules which leads to a very short half-life (Pope et al., 1998).

Other molecules that possess inhibitory activity against bacterial urease have been developed, but they are not fully adapted to treat UTIs. One of them is the quinones, a class of active compounds with a high oxidizing potency (Zaborska et al., 2002). These molecules had not been evaluated in vivo models due to their cytotoxic and cancerogenic properties.

\section{Small Compounds Targeting Bacterial Capsule}

Polysaccharide capsule biogenesis plays an important role in UPEC virulence. Like other pathogens, the capsule is used as a defense against opsonophagocytosis and complement-mediated killing (Roberts, 1995, 1996). The capsule is also involved in the 
formation of biofilm and the formation of intracellular bacterial communities (Llobet et al., 2008; Anderson et al., 2010). Until now, the human use of small-molecule inhibitors of UPEC capsule biogenesis was not available because of their antigenicity and poor bioavailability (Varki, 2008). Nevertheless, mouse studies identified two active agents (DU003 and DU01), that caused significant bacterial death (Goller et al., 2014; Figure 1).

\section{NUTRACEUTICALS}

Nutraceuticals are pharmaceutical alternatives, consisting of all the foods or food products which provide medical benefits and can be delivered under medical form. They provide health benefits in addition to their basic nutritional value.

\section{Cranberry (Vaccinium macrocarpon)}

Cranberry (Vaccinium macrocarpon Ait.) is a berry that grows in North America. In recent years, the use of cranberry has increased in the prophylactic approach of recurrent UTI (Howell et al., 2005). Although, its mechanism of action is unclear, there are several possible targets of cranberry (Figure 1).

The main efficacy is related to the antiadherence properties of cranberry (Ahuja et al., 1998; Liu et al., 2006) due to the A-type proanthocyanidin (PAC-A) that has been shown to be an important inhibitor of Type-I fimbriae E. coli adhesion to uroepithelial cells. Some in vitro and in vivo studies demonstrated the capacity of the cranberry to reduce the adhesion of bacteria to the cells (Ermel et al., 2012; Rafsanjany et al., 2015; Liu et al., 2019). Cranberry has also shown convincing results on motility and biofilm formation. Indeed, it has a negative impact on the swarming of Pseudomonas aeruginosa and P. mirabilis (Chan et al., 2013) and on the biofilm formation of E. faecalis, P. aeruginosa and E. coli (Ulrey et al., 2014; Rodríguez-Pérez et al., 2016; Wojnicz et al., 2016).

The use of cranberry has been associated with a decrease in the incidence of UTIs, although some conflicting results have been reported in the literature. Although cranberry products have been shown to significantly reduce the incidence of UTIs at 12 months (RR 0.65, 95\% CI 0.46-0.90) compared with placebo/control in women with recurrent UTIs in a Cochrane review from 2008 (Jepson and Craig, 2008), an updated review concluded that cranberry products did not show any significant reduction in the occurrence of symptomatic UTI in the same population (Jepson et al., 2012).

A placebo controlled trial, published after the last review, showed that women randomized to cranberry juice had a nonsignificant reduction in numbers of P-fimbriated E. coli in urine and in the rate of symptomatic UTIs (Stapleton et al., 2012).

Because dosage, concentration and formulation of PAC-A are not well defined, the conflicting results may be explained by the difference in PAC-A concentration between cranberry formulations (juice, beverage, tablets) in the different studies making it difficult to choose one formulation over another (Anger et al., 2019).

It must be noted that many of the products containing cranberry used in studies are only for research purposes, limiting the prophylactic application of cranberries beyond research (Stapleton et al., 2012).

Finally, a recent publication showed that the cranberry proanthocyanidins had a variable effect on a collection of E. coli strains that could explain the discordant results observed in the clinical studies (Ranfaing et al., 2018a).

In order to enhance the effectiveness of cranberry, combinations of cranberry and other natural products with antimicrobial properties could be used, such as propolis. Propolis is a resinous material collected by bees from plants then mixed with wax and bee enzymes (AFSSA, 2007). Propolis has antimicrobial, anti-inflammatory, anti-tumoral, immunemodulatory and anti-oxidant activities (Boonsai et al., 2014). It has been used for several years to treat gastrointestinal disorders (food supplement) (Freitas et al., 2006), to promote oral health (mouthwash) (Pereira et al., 2011) and in dermatological care (creams and ointments) (Olczyk et al., 2014; Pasupuleti et al., 2017; Ranfaing et al., 2018b). In vitro studies showed that propolis potentiated the effect of cranberry proanthocyanidins on adhesion, motility (swarming and swimming), biofilm formation (early formation and fully-formed biofilm), iron metabolism and stress response of UPEC (Olczyk et al., 2014; Pasupuleti et al., 2017; Ranfaing et al., 2018a,b). Moreover, this association was active in all the $E$. coli strains studied, ruling out the variable effect observed with the cranberry used alone (Ranfaing et al., 2018a).

A recent RCT versus placebo in 85 women with recurrent UTIs showed a slight reduction in the number of cystitis events in the first 3 months in the propolis and cranberry group after adjustment on water consumption (0.7 vs. 1.3, $p=0.02$ ), but no difference in the mean number of infections in women with at least one infection. Of note, the mean time to onset of the first cystitis episode was significantly longer in the propolis + cranberry group (70 vs. 43 days, $p=0.03$ ) and tolerance to the treatment was similar in both groups (Bruyère et al., 2019).

\section{Hyaluronic Acid}

The urinary bladder epithelium is composed of urothelial cells which carry specific sensors and properties as well as forming the first barrier to pathogens (Birder and de Groat, 2007). To maintain this capacity to fight infections, these cells produce sulfated polysaccharide glycosaminoglycan (GAG) which covers the epithelium and forms a non-specific anti-adherence factor. A major proportion of the GAG layer of the bladder is composed of hyaluronic acid (HA) and chondroitin sulfate (CS). Virulence factors (secreted by E. coli for example) damage the GAG layer to prepare its adhesion (Constantinides et al., 2004; Figure 1). One strategy for the management of UTI is based on the re-establishment of the GAG layer of the bladder epithelium with intravesical instillations of HA alone or in combination with CS. Various randomized and non-randomized studies have been performed.

A study investigated the impact of HA and CS on recurrent UTIs on 276 women (aged 18-75 years). The intravesical administration of HA and CS was given to 181 women and the standard treatment against recurrent UTIs was given to 95 
women. There was a $49 \%$ reduction in the rate of recurrence (defined as one bacteriologically confirmed UTI in the year following the treatment initiation) in patients treated with $\mathrm{HA}+\mathrm{CS}$ compared with standard care [adjusted OR 0.51 (95\%CI 0.27-0.96)]. However, no significant difference was found when considering the number of recurrences or the median time to first recurrence (Ciani et al., 2016).

Another retrospective study in 157 women found similar results with a significant reduction in UTI recurrence and an increased time-to-recurrence between UTIs (Cicione et al., 2014).

It has to be noted that the administration protocol (different between participating centers) of weekly instillation for one month followed by monthly instillations may be a limiting factor for patients.

A synergy might exist between HA + CS and estrogen. This association has been explored in 145 postmenopausal women with mild-to-moderate urogenital atrophy and a history of recurrent UTI. Participants were divided into three groups: vaginal estrogen, oral $\mathrm{HA}$, and oral $\mathrm{HA}+\mathrm{CS}$ and vaginal estrogen. Oral treatments were effective in preventing recurrent UTI (number of patients with fewer than two infective episodes in the 6-month follow-up and fewer than three episodes in the 12-month follow-up), especially if administered with vaginal estrogen therapy. A slight effect on the HA alone but also a significant impact of the estrogen and the HA + CS on the recurrence of UTIs in postmenopausal women was observed (Torella et al., 2016).

Recently a meta-analysis suggested that HA \pm CS decreased the rate of UTI recurrence and increased the time to recurrence (Goddard and Janssen, 2018). Moreover the authors noted the safety of HA therapy even if the intravesical instillation is more invasive than other administrations (usually per os). The combination therapy was more performant than the use of HA alone. It seems essential to perform a well-designed, randomized, controlled clinical trials with larger population.

\section{D-mannose}

As seen above, CUP pili are important virulence factors and represent optimal targets for antivirulence compound development. E. coli binds to mannosylated host cells via their mannose-binding lectin domains of FimH.

Two developments have been proposed to prevent this interaction:

- D-mannose is a monosaccharide closely related to glucose. It blocks the adhesion by high affinity binding to the FimH, thus preventing FimH from binding host mannose on urinary tract surfaces. Absorption after oral administration is fast (30 min to reach the organs) and it is eliminated via the urinary tract (Hills et al., 2001).

- The structure of the FimH adhesin bound to mannosilable proteins has been used to design mannosides, These molecules block FimH function by binding in the FimH mannose-binding pocket (Pinkner et al., 2006; Domenici et al., 2016). Mannosides are also potent inhibitors of biofilm formation in vitro. Some mouse models demonstrated a decrease in bladder colonization after an oral administration of mannosides and a prevention of acute and chronic UTI (Klein et al., 2010; Cusumano et al., 2011; Figure 1). In this way, an exogenous intake of D-mannose competitively blocks the interaction between the bacterial fimbriae and host cells (Cusumano et al., 2011; Figure 1). One RCT compared the recurrence of UTIs in a group of patients taking daily nitrofurantoin to a group treated with daily D-mannose powder. The risk of recurrence was similar between groups, whilst there was a reduction of the side effects in the D-mannose group (Kranjčec et al., 2014).

\section{Galabiose}

Type P fimbriae adhere to the galabiose-like receptor via PapG (Larsson et al., 2003). As previously noted, this kind of fimbriae is essential for the pathogenesis of UTIs in helping the bacteria to reach the kidneys (Strömberg et al., 1990). Better understanding of the structure of the different variants of PapG (mostly PapG II and PapG III) might lead to drugs designed to target this adhesin (Sung et al., 2001; Figure 1). No in vivo studies on the impact of this sugar on UTIs have yet been performed. Evaluation on the most prevalent uropathogenic bacteria is essential to clearly evaluate the potential of galabiose to reduce UTI.

\section{Vitamin C}

Vitamin C (ascorbic acid) is known to possess antioxidant and antimicrobial activities. As microbial infections cause reactive oxygen species (ROS) release by phagocytes, it is helpful in the limitation of infection through deactivation of microorganism killing. ROS may also cause damage to the host cells, therefore the level of ROS released by phagocytes should be reduced directly after infection (Liu et al., 2018). Vitamin C is an essential co-enzyme in the oxidative stress pathways, capable of ROS removal. Habash et al. (1999) suggested that vitamin C decreased the adhesion and microorganisms colonization of the biomaterials used in diagnostic/treatment procedures involving the urinary tract.

Moreover, two trials have studied the use of vitamin $\mathrm{C}$ to prevent UTIs. In a single-blind randomized study in thirteen spinal cord injury patients randomized to placebo or $500 \mathrm{mg}$ ascorbic acid four times daily, there was no clinical benefit on urinary infection from the use of ascorbic acid (Castelló et al., 1996). In a second single-blind randomized trial in 110 pregnant women, participants taking a vitamin regimen with $100 \mathrm{mg}$ ascorbic acid per day for 3 months showed a reduction in symptomatic UTIs incidence from 29.1 to $12.7 \%$ compared to participants following a vitamin regimen without ascorbic acid (Ochoa-Brust et al., 2007).

To date, there is no evidence of vitamin $\mathrm{C}$ action in the prevention of UTI.

\section{Chinese Herbal Medicine (CHM)}

Chinese Herbal Medicine (CHM) is the ancient art of compiling complex herbal formulae usually comprising up to 15 herbs. CHM has been historically used to treat UTI. Some frequently used Chinese herbs are known to have significant diuretic, 
antibiotic, immune enhancing, antipyretic, anti-inflammatory and pain relieving activities. Some of these herbs have shown an in vitro inhibitory activity against several uropathogens, especially against $E$. coli in decreasing its adherence to bladder epithelial cells (Tong et al., 2011). In an antibacterial test against mice, it was found that Sanjin tablets (composed by five kinds of CHM) have strong bacteriostasis activity (Hou and Wang, 2016). This product is used to treat acute uncomplicated lower UTI (Meng et al., 2015) and to reduce the symptoms of chronic UTI by reducing the secretory level of some urinary cytokines (Hou and Wang, 2016). A first meta-analysis of three RCTs including 282 women suggested that CHM significantly reduced recurrent UTI rates compared to antibiotics (RR 0.28, 95\%CI [0.09 to 0.82]) (Flower et al., 2015). The second one has concluded that the current evidence is insufficient to support the efficacity and safety of Sanjin tablets for acute uncomplicated lower UTI (Pu et al., 2016). Only two of these RCTs reported adverse events ( $\mathrm{Gu}$ et al., 2011; Zhao et al., 2011). Neither found any liver or renal impairment. Further studies are needed to definitively evaluate the potential of CHM on prevention/treatment of UTI.

\section{Other Phytochemicals}

For centuries, plants have been used as alternative and traditional medicine around the world notably as therapies for infectious diseases (Banu and Kumar, 2009; Sharifi-Rad et al., 2016). Plants and their secondary metabolic derivatives are a major resource of antioxidants due to the presence of phenolic compounds including flavonoids, phenolic acids, or tannins. Different extracts from plants and spices have demonstrated antiinflammatory, antimicrobial and diuretic activities (Mickymaray and Al Aboody, 2019). They also exhibited anti-quorum sensing and anti-biofilm potentials (Issac Abraham et al., 2011; Mazarei et al., 2017). One of the main mechanism of action is the antiadhesive action due to the formation of $\mathrm{H}$-bonds between the FimH protein ligand and the plant compounds (Jaiswal et al., 2018). Future clinical trials must be done after complete pharmacokinetic/pharmacodynamic analyses.

\section{IMMUNOMODULANT AGENTS}

The innate immune system activation through the secretion of cytokines and the recruitment of macrophages and neutrophils rapidly occurs after the onset of UTI (Duell et al., 2012). Even in the absence of an effective antibiotic treatment, this immune reaction might be enough to counter the infection. In the case of the persistence of several bacterial strains in the bladder, persistent acute immune response and tissue inflammation can be observed. Moreover, multiple infections can lead to chronic inflammation that increases the risk of developing recurrent UTIs (Ferry et al., 2004; Hannan et al., 2010). There is an increase in the expression of cyclooxygenase (COX)-2 after an infection of the bladder epithelial cells by UPEC. Moreover, there is a correlation between the severity of the inflammation and the increase of COX-2 expression (Chen et al., 2011; Figure 1). COX2 inhibition prevents urothelial transmigration by neutrophils and damage to the urothelial barrier and facilitates the innate responses (Hannan et al., 2014). A double-blind RCT on 79 women with uncomplicated UTI showed equivalent symptoms at Day 4, when taking ibuprofen (200 mg t.i.d) compared to ciprofloxacin (Bleidorn et al., 2010).

A recent $2 \times 2$ factorial placebo RCT evaluating ibuprofen in 382 women demonstrated a substantial reduction in antibiotic use in patients taking ibuprofen without differences in terms of symptom relief or speed of recovery (Moore et al., 2019).

Plant-based immunomodulants such as Green Tea Extract (GTE) have also shown promise (Bae et al., 2015). GTE contains an array of polyphenolic compounds, especially catechins. The biological properties of catechins are antioxidant, antiangiogenesis, antiproliferative activity, and antineoplastic (Cooper et al., 2005a,b). Some in vitro studies showed an antibacterial impact of GTE against UPEC (Hoshino et al., 1999; Arakawa et al., 2004; Reygaert and Jusufi, 2013) and in a rat model of cystitis, catechins significantly decreased inflammation and uroepithelium edema (Noormandi and Dabaghzadeh, 2015). These results are promising even though the mechanisms of action are still unclear.

\section{PROBIOTICS}

A probiotic is a live microorganism that confers a health benefit.

\section{Vaginal Lactobacilli}

Lactobacilli are frequently dominant microorganisms in vaginal flora (Mendling, 2016). Different observations can be done: (i) they have the ability to interfere with the adherence, growth and colonization of UPEC (Falagas et al., 2006); (ii) a change in the normal vaginal flora has been shown to facilitate the recurrence of UTIs (Cribby et al., 2008); and (iii) the use of commensal bacteria (such as Lactobacilli) reduces the proportion of uropathogens and thus restores bacterial homeostasis (Hardy et al., 2013). Although their exact mechanisms of action are still unknown, lactobacilli strains seem to have at least three different modes of action $(\mathrm{Ng}$ et al., 2018; Figure 1):

- The first one is the bacteriostatic effect due to the direct competition of probiotics with uropathogens in terms of nutrient and attachment sites (Di Cerbo et al., 2016).

- The second is the impact of probiotics on uropathogens virulence through the ability of Lactobacillus byproducts (such as lactic acid and hydrogen peroxide) to downregulate the expression of virulence genes. This has been illustrated in an in vitro study in which Lactobacillus byproducts inhibited the expression of Type 1 - and P-fimbriae-encoding genes in E. coli, disrupting adhesion and invasion capacity (Cadieux et al., 2009).

- The third is the bactericidal effect of Lactobacillus on uropathogens. This effect can be achieved through the production of antimicrobial peptides known as bacteriocins. These bacteriocins reduce the number of uropathogens (Chikindas et al., 2018) in a strain-specific manner (De Vuyst and Leroy, 2007). Lactobacillus species that produce bacteriocins against $E$. coli have been identified (Riaz et al., 2010). 
Probiotics can also modulate the immune system. In addition, bacterial strains secreting "immunomodulins" and cytokines are able to reduce infection by pathogenic bacteria (Galdeano and Perdigón, 2006; Kemgang et al., 2014). Lactobacillus species have these anti-inflammatory and immune-regulatory actions (Isolauri et al., 2001).

A non-inferiority randomized trial compared antibiotic prophylaxis and Lactobacillus prophylaxis in 252 postmenopausal women with recurrent UTIs who received 12 months of prophylaxis with trimethoprim-sulfamethoxazole (TMP-SMX), $480 \mathrm{mg}$ once daily or oral capsules containing $10^{9}$ CFU of Lactobacillus rhamnosus GR-1 and Lactobacillus reuteri RC-14 twice daily (Beerepoot et al., 2012b). The Lactobacillus treatment did not demonstrate non- inferiority, with an average number of symptomatic UTIs during the year of follow-up of 2.9 in the antibiotic group versus 3.3 in the lactobacilli group. The benefit of Lactobacilli was that it had no impact on antibiotic resistance compared to trimethoprimsulfamethoxazole.

A reduction in the recurrence rate of UTI with the use of lactobacilli products (pooled $\mathrm{RR}=0.68,95 \% \mathrm{CI} 0.44$ to $0.93, p<0.001$ ) (Ng et al., 2018) was underlined in a meta-analysis including 620 patients. In this study, two intravaginal suppositories (containing Lactobacillus crispatus CTV05, Lactobacillus rhamnosus GR1 and Lactobacillus reuteri RC14) had the highest efficacy (Ng et al., 2018).

A recent randomized, double-blind, placebo-controlled pilot study in 81 premenopausal women showed that the administration of Bio-Kult Pro-Cyan (a commercially available product containing probiotic strains (Lactobacillus acidophilus PXN 35, Lactobacillus plantarum PXN 47) and cranberry extract (36 mg/d PACs) twice-daily for 26 weeks, led to significantly lower number of recurrent UTIs compared to placebo (9.1 vs. 33.3\%; $P=0.0053$ ) (Koradia et al., 2019).

\section{Bacterial Interference: Escherichia coli Strain 83972}

The intentional colonization of the bladder with a non-virulent strain, also called bacterial interference, has been studied among patients with neurogenic bladder. E. coli 83972 is a clinical strain, isolated from a woman with chronic urinary colonization and which has naturally lost its capacity to develop Type 1 and Type P fimbriae. This strain has been used for prophylactic purposes to deliberately colonized the bladders with this bacterium to prevent colonization/infection by pathogenic species.

In a mouse model of UTI, E. coli 83972 demonstrated a better fitness than a virulent strain of UPEC. In a poor environment, like the bladder, this difference in fitness is a crucial advantage for the competition between bacteria. The 83972 strain could reduce the impact of UTIs by a monopolization of resources and space (Roos et al., 2006).

Seven clinical studies are available: three are RCT, one of which is a crossover designed study; and four are prospective cohorts (Hull et al., 2000; Darouiche et al., 2001, 2005; Dashiff et al., 2011; Trautner et al., 2007; Prasad et al., 2009; Sundén et al., 2010). Sample sizes were small and varied from 12 to 44 patients.
Clinical endpoints were the interval before first recurrence or the incidence of UTI during follow up.

Despite this heterogeneity, all studies demonstrated the ability of non-virulent strain to protect patients from UTI. One limit is the difficulty to achieve bladder colonization with the nonvirulent strain (only $38 \%$ of patients in one of the RCT) (Darouiche et al., 2011).

\section{Predatory Bacteria}

Predatory bacteria are small, motile, deltaproteobacteria that are a predatory invader of other Gram-negative bacteria (Figure 1). They occupy an intraperiplasmic niche and kill, digest and lyse their host, the prey cell. Bdellovibrio and Micavibrio are the most studied predatory bacteria (Stolp and Starr, 1963). Bdellovibrio bacteriovorus uses its type IV pilus to adhere and penetrate the outer membrane (bdelopast) of its prey. Inside the bacteria, $B$. bacteriovorus modifies the membrane of its prey to allow its growth until it uses all the nutrients. This entire process takes only 2-3 h (Sockett, 2009). Several Gram-negative human pathogenic bacteria such as E. coli, Klebsiella spp. and Pseudomonas spp. can be targeted by these predatory bacteria (Dashiff et al., 2011). Furthermore, it has been showed in vitro that $B$. bacteriovorus significantly reduced the quantity of biofilm (Kadouri and O'Toole, 2005).

In vitro and mouse model studies have underlined the fact that the predatory bacteria have no negative impact on human cell lines (Gupta et al., 2016) nor on animals (Shatzkes et al., 2015). B. dellovibrioa is thus a potential therapeutic agent, but has not been yet applied in this way. No studies have investigated B. bacteriovorus to treat UTIs to date. However, these bacteria offer an exciting path for further research where in vivo studies should be the focus.

\section{BACTERIOPHAGES}

Bacteriophages are viruses that parasitize a bacterium by infecting it and reproducing inside it and can act as bactericidal agents. Bacteriophage therapy is currently applied in different areas of medical research. Indeed, it has been recognized as an alternative treatment in localized infections such as otitis, infected burns and osteoarticular infections (Ferry et al., 2018; Jault et al., 2019). However, its use in UTI is scarce.

One research team has studied the combination of transurethral resection of prostate with bacteriophage therapy used instead of per operative antibiotics. They first demonstrated the in vitro lytic activity of commercial bacteriophage cocktails on $41 \mathrm{E}$. coli and $9 \mathrm{~K}$. pneumoniae strains. The lytic activity of the bacteriophage cocktails varied between $66 \%$ and $93 \%$. They also showed the potential of bacteriophage adaptation experiments to increase the lytic activity, leading to an increase from 66 to $93 \%$ for one of the cocktails (Sybesma et al., 2016).

In an animal model, Dufour et al. (2016) showed the ability of phage to treat an E. coli UTI. The administration of the same bacteriophage cocktail showed a significant reduction of the bacterial load in the E. coli kidney infection model as well as in the E. coli pneumonia model, but not in an E. coli sepsis model. 
In vivo studies were performed with a commercial preparation called Pyo bacteriophage, composed of bacteriophage lines active against a broad spectrum of uropathogenic bacteria: S. aureus, E. coli, Streptococcus spp. (including Enterococcus spp.), $P$. aeruginosa, and Proteus spp. in nine patients planned for transurethral resection. Bacteria load decreased in two-thirds of the patients (6/9), without any associated adverse events (Ujmajuridze et al., 2018).

One case report described the treatment of a recurrent $P$. aeruginosa UTI associated with a bilateral ureteral stent. A phage cocktail containing phages with activity against Streptococcus pyogenes, $S$ aureus, E. coli, P. aeruginosa, P. vulgaris, and $P$. mirabilis was administered. After 6 days of treatment, meropenem and colistin were started for 30 days. The results showed a 10 -fold reduction of bacteria load in the urine after the first 5 days of phage treatment. The bacterial load was undetectable after 2 days of subsequent antibiotic treatment. Urine samples remained sterile until 1 year after the end of the antibiotic treatment.

Another case report showed the treatment of a recurrent UTI with an ESBL-producing $K$. pneumoniae in a renal transplant patient whose infection evolved into an epididymitis. The patient was definitively cured after an oral and intravesical bacteriophage treatment of 10 days following 6-week meropenem treatment (Kuipers et al., 2019).

One randomized, double-blind trial versus placebo in patients planned for transurethral resection of the prostate with UTI is ongoing. Patients will be randomized in a 1:1:1 ratio to receive 7 days of either: (i) bacteriophage (Pyo bacteriophage) solution, (ii) placebo solution, or (iii) antibiotic treatment (Leitner et al., 2017).

More human studies are warranted to further define the role of this treatment option in UTIs.

\section{CONCLUSION}

Although prophylactic antibiotics remain the preferred preventive treatment in recurrent UTIs, the emergence of antimicrobial resistance worldwide has made the development of non-antibiotics strategies a priority. The better understanding of UTI mechanisms will help direct future research on the topic. Indeed, recent studies have revealed that infection with UPEC and a number of other Gram-negative uropathogens proceeds through dynamic intracellular and extracellular host niches during the course of acute and chronic infection.

Several targets such as uropathogenic adhesins, toxins, urease, iron metabolism and motility have been explored. Although

\section{REFERENCES}

Åberg, V., and Almqvist, F. (2007). Pilicides-small molecules targeting bacterial virulence. Org. Biomol. Chem. 5, 1827-1834. doi: 10.1039/b702397a

Abraham, S. N., and Miao, Y. (2015). The nature of immune responses to urinary tract infections. Nat. Rev. Immunol. 15, 655-663. doi: 10.1038/nri3887

AFSSA (2007). Saisine $n^{\circ}$ 2007. Available online at: https://www.anses.fr/fr/system/ files/DIVE2007sa0209.pdf (accessed January 13, 2009). non-antibiotic prophylactic agents appear to be well tolerated and do not seem to increase the antimicrobial resistance of the commensal flora, most of therapeutic options displayed in this review are still preliminary.

Other approaches have also been evaluated in prevention of CAUTI. In case of prolonged utilization of catheter, some techniques have been developed to prevent bacterial growth and biofilm formation. These techniques, including the devices with antimicrobial coatings such as silver, peptides, enzymes or bacteriophages, provide minimal reduction in infection incidence and will need further assessment (Percival et al., 2015; Al-Qahtani et al., 2019).

While Lactobacillus-containing products appear to be the most promising new alternative to currently used antibiotics, cranberry products combined with propolis would need further investigations. Studies should now be designed to investigate the interaction between non-antibiotic therapies, uropathogens and the host immune system. Importantly, clinical trials must use standardized definitions of UTI (infection versus colonization based on urinary symptoms), treatment regimens and control groups as well as an assessment of the risk/benefit ratio especially on tolerance and antibiotic resistance and an economic evaluation of the reviewed therapeutics versus prolonged antibiotic treatments. Likewise, further research is needed for vaccines, which have shown potential in initial trials.

\section{AUTHOR CONTRIBUTIONS}

PL, JR, J-PL, and AS wrote the manuscript. AD, CD-R, LB, and FB critically reviewed the manuscript. All authors contributed to the article and approved the submitted version.

\section{FUNDING}

This work was supported by CHU Nîmes (Grant Thématiques phares).

\section{ACKNOWLEDGMENTS}

PL, CD-R, AS and J-PL belong to the FHU INCh (Federation Hospitalo Universitaire Infections Chroniques, Aviesan). We thank the Nîmes University hospital for its structural, human and financial support through the award obtained by our team during the internal call for tenders Thématiques phares. We also thank Sarah Kabani for her editing assistance.

Ahuja, S., Kaack, B., and Roberts, J. (1998). Loss of fimbrial adhesion with the addition of Vaccinum macrocarpon to the growth medium of P-fimbriated Escherichia coli. J. Urol. 159, 559-562. doi: 10.1016/s0022-5347(01)63983-1

Albert, X., Huertas, I., Pereiro, I., Sanfélix, J., Gosalbes, V., and Perrotta, C. (2004). Antibiotics for preventing recurrent urinary tract infection in non-pregnant women. Cochrane Database Syst. Rev. 3:CD001209.

Al-Qahtani, M., Safan, A., Jassim, G., and Abadla, S. (2019). Efficacy of antimicrobial catheters in preventing catheter associated urinary tract infections 
in hospitalized patients: a review on recent updates. J. Infect. Public Health 12, 760-766. doi: 10.1016/j.jiph.2019.09.009

Alteri, C. J., Hagan, E. C., Sivick, K. E., Smith, S. N., and Mobley, H. L. T. (2009). Mucosal immunization with iron receptor antigens protects against urinary tract infection. PLoS Pathog. 5:e1000586. doi: 10.1371/journal.ppat.1000586

Amtul, Z., Rahman, A.-U., Siddiqui, R. A., and Choudhary, M. I. (2002). Chemistry and mechanism of urease inhibition. Curr. Med. Chem. 9, 1323-1348. doi: $10.2174 / 0929867023369853$

Anderson, G. G., Goller, C. C., Justice, S., Hultgren, S. J., and Seed, P. C. (2010). Polysaccharide capsule and sialic acid-mediated regulation promote biofilmlike intracellular bacterial communities during cystitis. Infect. Immun. 78, 963-975. doi: 10.1128/iai.00925-09

Anger, J., Lee, U., Ackerman, A. L., Chou, R., Chughtai, B., Clemens, J. Q., et al. (2019). Recurrent uncomplicated urinary tract infections in women: AUA/CUA/SUFU guideline. J. Urol. 202, 282-289. doi: 10.1097/ju. 0000000000000296

Arakawa, H., Maeda, M., Okubo, S., and Shimamura, T. (2004). Role of hydrogen peroxide in bactericidal action of catechin. Biol. Pharm. Bull. 27, 277-281. doi: $10.1248 / \mathrm{bpb} .27 .277$

Asadi Karam, M. R., Habibi, M., and Bouzari, S. (2019). Urinary tract infection: pathogenicity, antibiotic resistance and development of effective vaccines against Uropathogenic Escherichia coli. Mol. Immunol. 108, 56-67. doi: 10. 1016/j.molimm.2019.02.007

Aziminia, N., Hadjipavlou, M., Philippou, Y., Pandian, S. S., Malde, S., and Hammadeh, M. Y. (2019). Vaccines for the prevention of recurrent urinary tract infections: a systematic review. BJU Int. 123, 753-768. doi: 10.1111/bju. 14606

Bae, W.-J., Ha, U.-S., Kim, S., Kim, S.-J., Hong, S.-H., Lee, J.-Y., et al. (2015). Reduction of oxidative stress may play a role in the anti-inflammatory effect of the novel herbal formulation in a rat model of hydrochloric acid-induced cystitis. Neurourol. Urodyn. 34, 86-91. doi: 10.1002/nau.22507

Bailie, N. C., Osborne, C. A., Leininger, J. R., Fletcher, T. F., Johnston, S. D., Ogburn, P. N., et al. (1986). Teratogenic effect of acetohydroxamic acid in clinically normal beagles. Am. J. Vet. Res. 47, 2604-2611.

Banu, G. S., and Kumar, G. (2009). Preliminary screening of endophytic fungi from medicinal plants in India for antimicrobial and antitumor activity. Int. J. Pharma. Sci. Nanothechnol. 2, 566-571.

Bauer, H. W., Alloussi, S., Egger, G., Blümlein, H.-M., Cozma, G., Schulman, C. C., et al. (2005). A long-term, multicenter, double-blind study of an Escherichia coli extract (OM-89) in female patients with recurrent urinary tract infections. Eur. Urol. 47, 542-548. doi: 10.1016/j.eururo.2004.12.009

Beerepoot, M., and Geerlings, S. (2016). Non-antibiotic prophylaxis for urinary tract infections. Pathogens 5:36. doi: 10.3390/pathogens5020036

Beerepoot, M. A. J., den Heijer, C. D. J., Penders, J., Prins, J. M., Stobberingh, E. E., and Geerlings, S. E. (2012a). Predictive value of Escherichia coli susceptibility in strains causing asymptomatic bacteriuria for women with recurrent symptomatic urinary tract infections receiving prophylaxis. Clin. Microbiol. Infect. 18, E84-E90.

Beerepoot, M. A. J., ter Riet, G., Nys, S., van der Wal, W. M., de Borgie, C. A. J. M., de Reijke, T. M., et al. (2012b). Lactobacilli vs antibiotics to prevent urinary tract infections: a randomized, double-blind, noninferiority trial in postmenopausal women. Arch. Intern. Med. 172, 704-712.

Benini, S., Rypniewski, W. R., Wilson, K. S., Miletti, S., Ciurli, S., and Mangani, S. (2000). The complex of Bacillus pasteurii urease with acetohydroxamate anion from X-ray data at 1.55 A resolution. J. Biol. Inorg. Chem. 5, 110-118. doi: $10.1007 /$ s007750050014

Birder, L. A., and de Groat, W. C. (2007). Mechanisms of disease: involvement of the urothelium in bladder dysfunction. Nat. Clin. Pract. Urol. 4, 46-54. doi: $10.1038 /$ ncpuro0672

Bleidorn, J., Gágyor, I., Kochen, M. M., Wegscheider, K., and Hummers-Pradier, E. (2010). Symptomatic treatment (ibuprofen) or antibiotics (ciprofloxacin) for uncomplicated urinary tract infection?-results of a randomized controlled pilot trial. BMC Med. 8:30. doi: 10.1186/1741-7015-8-30

Boonsai, P., Phuwapraisirisan, P., and Chanchao, C. (2014). Antibacterial activity of a cardanol from Thai Apis mellifera propolis. Int. J. Med. Sci. 11, 327-336. doi: 10.7150/ijms.7373

Brumbaugh, A. R., Smith, S. N., and Mobley, H. L. T. (2013). Immunization with the yersiniabactin receptor, FyuA, protects against pyelonephritis in a murine model of urinary tract infection. Infect. Immun. 81, 3309-3316. doi: 10.1128/ iai.00470-13

Bruyère, F., Azzouzi, A. R., Lavigne, J.-P., Droupy, S., Coloby, P., Game, X., et al. (2019). A multicenter, randomized, placebo-controlled study evaluating the efficacy of a combination of propolis and cranberry (Vaccinium macrocarpon) $\left(\mathrm{DUAB}^{\circledR}\right)$ in preventing low urinary tract Infection recurrence in women complaining of recurrent cystitis. Urol. Int. 103, 41-48. doi: 10.1159/000496695

Burne, R. A., and Chen, Y. Y. M. (2000). Bacterial ureases in infectious diseases. Microbes Infect. 2, 533-542. doi: 10.1016/s1286-4579(00)00312-9

Cadieux, P. A., Burton, J., Devillard, E., and Reid, G. (2009). Lactobacillus byproducts inhibit the growth and virulence of uropathogenic Escherichia coli. J. Physiol. Pharmacol. 60, 13-18.

Castelló, T., Girona, L., Gómez, M. R., Mena Mur, A., and García, L. (1996). The possible value of ascorbic acid as a prophylactic agent for urinary tract infection. Spinal Cord. 34, 592-593. doi: 10.1038/sc.1996.105

Cegelski, L., Pinkner, J. S., Hammer, N. D., Cusumano, C. K., Hung, S., Chorell, E., et al. (2010). Small-molecule inhibitors target Escherichia coli amyloid biogenesis and biofilm formation. Natl. Inst. Health 5, 913-919. doi: 10.1038/ nchembio. 242

Chan, M., Hidalgo, G., Asadishad, B., Almeida, S., Muja, N., Mohammadi, M. S., et al. (2013). Inhibition of bacterial motility and spreading via release of cranberry derived materials from silicone substrates. Colloids Surf. B Biointerfaces 110, 275-280. doi: 10.1016/j.colsurfb.2013.03.047

Chen, T.-C., Tsai, J.-P., Huang, H.-J., Teng, C.-C., Chien, S.-J., Kuo, H.-C., et al. (2011). Regulation of cyclooxygenase-2 expression in human bladder epithelial cells infected with type I fimbriated uropathogenic E. coli. Cell. Microbiol. 13, 1703-1713. doi: 10.1111/j.1462-5822.2011.01650.x

Chikindas, M. L., Weeks, R., Drider, D., Chistyakov, V. A., and Dicks, L. M. (2018). Functions and emerging applications of bacteriocins. Curr. Opin. Biotechnol. 49, 23-28. doi: 10.1016/j.copbio.2017.07.011

Ciani, O., Arendsen, E., Romancik, M., Lunik, R., Costantini, E., Di Biase, M., et al. (2016). Intravesical administration of combined hyaluronic acid (HA) and chondroitin sulfate (CS) for the treatment of female recurrent urinary tract infections: a European multicentre nested case-control study. BMJ Open 6:e09669. doi: 10.1136/bmjopen-2015-009669

Cicione, A., Cantiello, F., Ucciero, G., Salonia, A., Torella, M., De Sio, M., et al. (2014). Intravesical treatment with highly-concentrated hyaluronic acid and chondroitin sulphate in patients with recurrent urinary tract infections: results from a multicentre survey. J. Can. Urol. Assoc. 8, E721-E727.

Constantinides, C., Manousakas, T., Nikolopoulos, P., Stanitsas, A., Haritopoulos, K., and Giannopoulos, A. (2004). Prevention of recurrent bacterial cystitis by intravesical administration of hyaluronic acid: a pilot study. BJU Int. 93, 1262-1266. doi: 10.1111/j.1464-410x.2004.04850.x

Cooper, R., Morré, D. J., and Morré, D. M. (2005a). Medicinal benefits of green tea: Part I. Review of noncancer health benefits. J. Altern. Complement. Med. 11, 521-528. doi: 10.1089/acm.2005.11.521

Cooper, R., Morré, D. J., and Morré, D. M. (2005b). Medicinal benefits of green tea: Part II. Review of anticancer properties. J. Altern. Complement. Med. 11, 639-652. doi: 10.1089/acm.2005.11.639

Cribby, S., Taylor, M., and Reid, G. (2008). Vaginal microbiota and the use of probiotics. Interdiscip. Perspect. Infect. Dis. 2008:256490.

Cusumano, C. K., Pinkner, J. S., Han, Z., Greene, S. E., Ford, B. A., Crowley, J. R., et al. (2011). Treatment and prevention of urinary tract infection with orally active FimH inhibitors. Sci. Transl. Med. 3:109ra115. doi: 10.1126/scitranslmed. 3003021

Darouiche, R. O., Donovan, W. H., Del Terzo, M., Thornby, J. I., Rudy, D. C., and Hull, R. A. (2001). Pilot trial of bacterial interference for preventing urinary tract infection. Urology 58, 339-344. doi: 10.1016/s0090-4295(01)01271-7

Darouiche, R. O., Green, B. G., Donovan, W. H., Chen, D., Schwartz, M., Merritt, J., et al. (2011). Multicenter randomized controlled trial of bacterial interference for prevention of urinary tract infection in patients with neurogenic bladder. Urology 78, 341-346. doi: 10.1016/j.urology.2011.03.062

Darouiche, R. O., Thornby, J. I., Stewart, C. C., Donovan, W. H., and Hull, R. A. (2005). Bacterial Interference for prevention of urinary tract infection: a prospective, randomized, placebo-controlled, double-blind pilot trial. Clin. Infect. Dis. 41, 1531-1534. doi: 10.1086/497272

Dashiff, A., Junka, R. A., Libera, M., and Kadouri, D. E. (2011). Predation of human pathogens by the predatory bacteria Micavibrio aeruginosavorus and 
Bdellovibrio bacteriovorus. J. Appl. Microbiol. 110, 431-444. doi: 10.1111/j. 1365-2672.2010.04900.x

De Ree, J. M., and Van den Bosch, J. F. (1987). Serological response to the P fimbriae of uropathogenic Escherichia coli in pyelonephritis. Infect. Immun. 55, 2204-2207. doi: 10.1128/iai.55.9.2204-2207.1987

De Vuyst, L., and Leroy, F. (2007). Bacteriocins from lactic acid bacteria: production, purification, and food applications. J. Mol. Microbiol. Biotechnol. 13, 194-199. doi: 10.1159/000104752

Di Cerbo, A., Palmieri, B., Aponte, M., Morales-Medina, J. C., and Iannitti, T. (2016). Mechanisms and therapeutic effectiveness of lactobacilli. J. Clin. Pathol. 69, 187-203. doi: 10.1136/jclinpath-2015-202976

Dinh, A., Hallouin-Bernard, M. C., Davido, B., Lemaignen, A., Bouchand, F., Duran, C., et al. (2019). Weekly sequential antibioprophylaxis for recurrent UTI among patients with neurogenic bladder: a randomized controlled trial. Clin. Infect. Dis. ciz1207. doi: 10.1093/cid/ciz1207. [Epub ahead of print].

Domenici, L., Monti, M., Bracchi, C., Giorgini, M., Colagiovanni, V., Muzii, L., et al. (2016). D-mannose: a promising support for acute urinary tract infections in women. A pilot study. Eur. Rev. Med. Pharmacol. Sci. 20, 2920-2925.

Duell, B. L., Carey, A. J., Tan, C. K., Cui, X., Webb, R. I., Totsika, M., et al. (2012). Innate transcriptional networks activated in bladder in response to uropathogenic Escherichia coli drive diverse biological pathways and rapid synthesis of IL-10 for defense against bacterial urinary tract infection. J. Immunol. 188, 781-792. doi: 10.4049/jimmunol.1101231

Dufour, N., Clermont, O., La Combe, B., Messika, J., Dion, S., Khanna, V., et al. (2016). Bacteriophage LM33_P1, a fast-acting weapon against the pandemic ST131-O25b:H4 Escherichia coli clonal complex. J. Antimicrob. Chemother. 71, 3072-3080. doi: 10.1093/jac/dkw253

Ellis, T. N., and Kuehn, M. J. (2010). Virulence and immunomodulatory roles of bacterial outer membrane vesicles. Microbiol. Mol. Biol. Rev. 74, 81-94. doi: $10.1128 / \mathrm{mmbr} .00031-09$

Ermel, G., Georgeault, S., Inisan, C., and Besnard, M. (2012). Inhibition of adhesion of uropathogenic Escherichia coli Bacteria to uroepithelial cells by extracts from cranberry. J. Med. Food 15, 126-134. doi: 10.1089/jmf.2010. 0312

Falagas, M. E., Betsi, G. I., Tokas, T., and Athanasiou, S. (2006). Probiotics for prevention of recurrent urinary tract infections in women : a review of the evidence from microbiological and clinical studies. Drugs 66, 1253-1261. doi: 10.2165/00003495-200666090-00007

Faraci, W. S., Yang, B. V., O’Rourke, D., and Spencer, R. W. (1995). Inhibition of Helicobacter pylori urease by phenyl phosphorodiamidates: mechanism of action. Bioorg. Med. Chem. 3, 605-610. doi: 10.1016/0968-0896(95)00043-g

Ferry, S. A., Holm, S. E., Stenlund, H., Lundholm, R., and Monsen, T. J. (2004). The natural course of uncomplicated lower urinary tract infection in women illustrated by a randomized placebo controlled study. Scand. J. Infect. Dis. 36, 296-301. doi: 10.1080/00365540410019642

Ferry, T., Boucher, F., Fevre, C., Perpoint, T., Chateau, J., Petitjean, C., et al. (2018). Innovations for the treatment of a complex bone and joint infection due to XDR Pseudomonas aeruginosa including local application of a selected cocktail of bacteriophages. J. Antimicrob. Chemother. 73, 2901-2903. doi: 10.1093/jac/ dky263

Flores-Meireles, A., Walker, J., Caparon, M., and Hultgren, S. (2015). Urinary tract infections: epidemiology, mechanisms of infection and treatment options. Nat. Rev. Microbiol. 13, 269-284. doi: 10.1038/nrmicro3432

Flower, A., Wang, L.-Q., Lewith, G., Liu, J. P., and Li, Q. (2015). Chinese herbal medicine for treating recurrent urinary tract infections in women. Cochrane Database Syst. Rev. 2015:CD010446.

Foxman, B. (2014). Urinary tract infection syndromes: occurrence, recurrence, bacteriology, risk factors, and disease burden. Infect. Dis. Clin. North Am. 28, 1-13. doi: $10.1016 /$ j.idc.2013.09.003

Freitas, S. F., Shinohara, L., Sforcin, J. M., and Guimarães, S. (2006). In vitro effects of propolis on Giardia duodenalis trophozoites. Phytomedicine 13, 170-175. doi: 10.1016/j.phymed.2004.07.008

Frenck, R. W., Ervin, J., Chu, L., Abbanat, D., Spiessens, B., Go, O., et al. (2019). Safety and immunogenicity of a vaccine for extra-intestinal pathogenic Escherichia coli (ESTELLA): a phase 2 randomised controlled trial. Lancet Infect. Dis. 19, 631-640. doi: 10.1016/s1473-3099(18)30803-x

Galdeano, C. M., and Perdigón, G. (2006). The probiotic bacterium Lactobacillus casei induces activation of the gut mucosal immune system through innate immunity. Clin. Vaccine Immunol. 13, 219-226. doi: 10.1128/cvi.13.2.219-226. 2006

Goddard, J. C., and Janssen, D. A. W. (2018). Intravesical hyaluronic acid and chondroitin sulfate for recurrent urinary tract infections: systematic review and meta-analysis. Int. Urogynecol. J. 29, 933-942. doi: 10.1007/s00192-017-3508-z

Goller, C. C., Arshad, M., Noah, J. W., Ananthan, S., Evans, C. W., Nebane, N. M., et al. (2014). Lifting the mask: identification of new small molecule inhibitors of uropathogenic Escherichia coli group 2 capsule biogenesis. PLoS One 9:e96054. doi: 10.1371/journal.pone.0096054

Greene, S. E., Pinkner, J. S., Chorell, E., Dodson, K. W., Shaffer, C. L., Conover, M. S., et al. (2014). Pilicide ec240 disrupts virulence circuits in uropathogenic Escherichia coli. mBio 5:14.

Griffith, D. P., Gibson, J. R., Clinton, C. W., and Musher, D. M. (1978). Acetohydroxamic acid: clinical studies of a urease inhibitor in patients with staghorn renal calculi. J. Urol. 119, 9-15. doi: 10.1016/s0022-5347(17)57366-8

Griffith, D. P., Gleeson, M. J., Lee, H., Longuet, R., Deman, E., and Earle, N. (1991). Randomized, double-blind trial of Lithostat (acetohydroxamic acid) in the palliative treatment of infection-induced urinary calculi. Eur. Urol. 20, 243-247. doi: 10.1159/000471707

Griffith, D. P., Khonsari, F., Skurnick, J. H., and James, K. E. (1988). A randomized trial of acetohydroxamic acid for the treatment and prevention of infectioninduced urinary stones in spinal cord injury patients. J. Urol. 140, 318-324. doi: 10.1016/s0022-5347(17)41592-8

Gu, X. C., Xu, Z., Chen, M., and Wang, M. (2011). Study of erding erxian docoction compared with sanjin tablet in treating recurrent urinary tract infection. Zhongguo Zhongxiyi Jiehe Shenbing Zazhi. 12, 623-624.

Gupta, S., Tang, C., Tran, M., and Kadouri, D. E. (2016). Effect of predatory bacteria on human cell lines. PLoS One 11:e161242. doi: 10.1371/journal.pone.0161242

Habash, M. B., Van der Mei, H. C., Busscher, H. J., and Reid, G. (1999). The effect of water, ascorbic acid, and cranberry derived supplementation on human urine and uropathogen adhesion to silicone rubber. Can. J. Microbiol. 45, 691-694. doi: 10.1139/w99-065

Habibi, M., Asadi Karam, M. R., and Bouzari, S. (2016). Transurethral instillation with fusion protein $\mathrm{MrpH}$.FimH induces protective innate immune responses against uropathogenic Escherichia coli and Proteus mirabilis. APMIS 124, 444452. doi: $10.1111 /$ apm. 12523

Hannan, T. J., Mysorekar, I. U., Hung, C. S., Isaacson-Schmid, M. L., and Hultgren, S. J. (2010). Early severe inflammatory responses to uropathogenic E. coli predispose to chronic and recurrent urinary tract infection. PLOS Pathog. 6:e1001042. doi: 10.1371/journal.ppat.1001042

Hannan, T. J., Roberts, P. L., Riehl, T. E., van der Post, S., Binkley, J. M., Schwartz, D. J., et al. (2014). Inhibition of cyclooxygenase-2 prevents chronic and recurrent cystitis. EBioMedicine 1, 46-57. doi: 10.1016/j.ebiom.2014.10.011

Hardy, H., Harris, J., Lyon, E., Beal, J., and Foey, A. D. (2013). Probiotics, prebiotics and immunomodulation of gut mucosal defences: homeostasis and immunopathology. Nutrients 5, 1869-1912. doi: 10.3390/nu5061869

Hills, A. E., Patel, A., Boyd, P., and James, D. C. (2001). Metabolic control of recombinant monoclonal antibody N-glycosylation in GS-NS0 cells. Biotechnol. Bioeng. 75, 239-251. doi: 10.1002/bit.10022

Hopkins, W. J., Elkahwaji, J., Beierle, L. M., Leverson, G. E., and Uehling, D. T. (2007). Vaginal mucosal vaccine for recurrent urinary tract infections in women: results of a phase 2 clinical trial. J. Urol. 177, 1349-1353. doi: 10.1016/j.juro.2006.11.093

Hoshino, N., Kimura, T., Yamaji, A., and Ando, T. (1999). Damage to the cytoplasmic membrane of Escherichia coli by catechin-copper (II) complexes. Free Radic. Biol. Med. 27, 1245-1250. doi: 10.1016/s0891-5849(99)00157-4

Hou, X., and Wang, L. X. (2016). Research progress of sanjin tablets. Eval. Anal. Drug Chin. Hosp. 16, 1148-1151.

Howell, A. B., Reed, J. D., Krueger, C. G., Winterbottom, R., Cunningham, D. G., and Leahy, M. (2005). A-type cranberry proanthocyanidins and uropathogenic bacterial anti-adhesion activity. Phytochemistry 66, 2281-2291. doi: 10.1016/j. phytochem.2005.05.022

Huber, M., Ayoub, M., Pfannes, S. D., Mittenbühler, K., Weis, K., Bessler, W. G., et al. (2000). Immunostimulatory activity of the bacterial extract OM-8. Eur. J. Med. Res. 5, 101-109.

Hull, R., Rudy, D., Donovan, W., Svanborg, C., Wieser, I., Stewart, C., et al. (2000). Urinary tract infection prophylaxis using Escherichia coli 83972 in spinal cord injured patients. J. Urol. 163, 872-877. doi: 10.1016/s0022-5347(05)67823-8 
Huttner, A., and Gambillara, V. (2018). The development and early clinical testing of the ExPEC4V conjugate vaccine against uropathogenic Escherichia coli. Clin. Microbiol. Infect. 24, 1046-1050. doi: 10.1016/j.cmi.2018.05.009

Huttner, A., Hatz, C., van den Dobbelsteen, G., Abbanat, D., Hornacek, A., Frölich, R., et al. (2017). Safety, immunogenicity, and preliminary clinical efficacy of a vaccine against extraintestinal pathogenic Escherichia coli in women with a history of recurrent urinary tract infection: a randomised, single-blind, placebocontrolled phase $1 \mathrm{~b}$ trial. Lancet Infect. Dis. 17, 528-537. doi: 10.1016/s14733099(17)30108-1

Ikähelmo, R., Siitonen, A., Heiskanen, T., Kärkkäinen, U., Kuosmanen, P., Lipponen, P., et al. (1996). Recurrence of urinary tract infection in a primary care setting: analysis of a I-year follow-up of 179 women. Clin. Infect. Dis. 22, 91-99. doi: 10.1093/clinids/22.1.91

Ingersoll, M. A., and Albert, M. L. (2013). From infection to immunotherapy: host immune responses to bacteria at the bladder mucosa. Mucosal Immunol. 6, 1041-1053. doi: $10.1038 / \mathrm{mi} .2013 .72$

Isolauri, E., Sütas, Y., Kankaanpää, P., Arvilommi, H., and Salminen, S. (2001). Probiotics: effects on immunity. Am. J. Clin. Nutr. 73, 444S-450S.

Issac Abraham, S. V., Palani, A., Ramaswamy, B. R., Shunmugiah, K. P., and Arumugam, V. R. (2011). Antiquorum sensing and antibiofilm potential of Capparis spinosa. Arch. Med. Res. 42, 658-668. doi: 10.1016/j.arcmed.2011.12. 002

Jacobsen, S. M., Stickler, D. J., Mobley, H. L. T., and Shirtliff, M. E. (2008). Complicated catheter-associated urinary tract infections due to Escherichia coli and Proteus mirabilis. Clin. Microbiol. Rev. 21, 26-59. doi: 10.1128/cmr.0001907

Jaiswal, S. K., Sharma, N. K., Bharti, S. K., Krishnan, S., Kumar, A., Prakash, O., et al. (2018). Phytochemicals as uropathogenic Escherichia coli FimH antagonist: in vitro and in silico approach. Curr. Mol. Med. 18, 640-653. doi: 10.2174/ 1566524019666190104104507

Jault, P., Leclerc, T., Jennes, S., Pirnay, J. P., Que, Y.-A., Resch, G., et al. (2019). Efficacy and tolerability of a cocktail of bacteriophages to treat burn wounds infected by Pseudomonas aeruginosa (PhagoBurn): a randomised, controlled, double-blind phase 1/2 trial. Lancet Infect. Dis. 19, 35-45. doi: 10.1016/s14733099(18)30482-1

Jepson, R. G., and Craig, J. C. (2008). Cranberries for preventing urinary tract infections. Cochrane Database Syst. Rev. CD001321. doi: 10.1002/14651858. CD001321.pub4

Jepson, R. G., Williams, G., and Craig, J. C. (2012). Cranberries for preventing urinary tract infections. Cochrane Database Syst. Rev. 10:CD001321.

Johnson, J. R. (1991). Virulence factors in Escherichia coli urinary tract infection. Clin. Microbiol. Rev. 4, 80-128. doi: 10.1128/cmr.4.1.80

Kadouri, D., and O'Toole, G. A. (2005). Susceptibility of biofilms to Bdellovibrio bacteriovorus attack. Appl. Environ. Microbiol. 71, 4044-4051. doi: 10.1128/ aem.71.7.4044-4051.2005

Kaijser, B., Larsson, P., Olling, S., and Schneerson, R. (1983). Protection against acute, ascending pyelonephritis caused by Escherichia coli in rats, using isolated capsular antigen conjugated to bovine serum albumin. Infect. Immun. 39, 142-146. doi: 10.1128/iai.39.1.142-146.1983

Kemgang, T. S., Kapila, S., Shanmugam, V. P., and Kapila, R. (2014). Cross-talk between probiotic lactobacilli and host immune system. J. Appl. Microbiol. 117, 303-319. doi: 10.1111/jam.12521

Klein, T., Abgottspon, D., Wittwer, M., Rabbani, S., Herold, J., Jiang, X., et al. (2010). FimH antagonists for the oral treatment of urinary tract infections: from design and synthesis to in vitro and in vivo evaluation. J. Med. Chem. 53, 8627-8641. doi: 10.1021/jm101011y

Koradia, P., Kapadia, S., Trivedi, Y., Chanchu, G., and Harper, A. (2019). Probiotic and cranberry supplementation for preventing recurrent uncomplicated urinary tract infections in premenopausal women: a controlled pilot study. Exp. Rev. Anti Infect. Ther. 17, 733-740. doi: 10.1080/14787210.2019.1664287

Kranjčec, B., Papes, D., and Altarac, S. (2014). D-mannose powder for prophylaxis of recurrent urinary tract infections in women: a randomized clinical trial. World J. Urol. 32, 79-84. doi: 10.1007/s00345-013-1091-6

Kuipers, S., Ruth, M. M., Mientjes, M., de Sévaux, R. G. L., and van Ingen, J. A. (2019). Dutch case report of successful treatment of chronic relapsing urinary tract infection with bacteriophages in a renal transplant patient. Antimicrob. Agents Chemother. 64:e01281-19.
Kumar, V., Ganguly, N., Joshi, K., Mittal, R., Harjai, K., Chhibber, S., et al. (2005). Protective efficacy and immunogenicity of Escherichia coli K13 diphtheria toxoid conjugate against experimental ascending pyelonephritis. Med. Microbiol. Immunol. 194, 211-217. doi: 10.1007/s00430-005-0241-x

Langermann, S., Möllby, R., Burlein, J. E., Palaszynski, S. R., Auguste, C. G., DeFusco, A., et al. (2000). Vaccination with FimH adhesin protects cynomolgus monkeys from colonization and infection by uropathogenic Escherichia coli. J. Infect. Dis. 181, 774-778. doi: 10.1086/315258

Larsson, A., Ohlsson, J., Dodson, K. W., Hultgren, S. J., Nilsson, U., and Kihlberg, J. (2003). Quantitative studies of the binding of the class II PapG adhesin from uropathogenic Escherichia coli to oligosaccharides. Bioorg. Med. Chem. 11, 2255-2261. doi: 10.1016/s0968-0896(03)00114-7

Laupland, K. B., Ross, T., Pitout, J. D. D., Church, D. L., and Gregson, D. B. (2007). Community-onset urinary tract infections: a population-based assessment. Infection 35, 150-153. doi: 10.1007/s15010-007-6180-2

Leitner, L., Sybesma, W., Chanishvili, N., Goderdzishvili, M., Chkhotua, A., Ujmajuridze, A., et al. (2017). Bacteriophages for treating urinary tract infections in patients undergoing transurethral resection of the prostate: a randomized, placebo-controlled, double-blind clinical trial. BMC Urol. 17:90. doi: 10.1186/s12894-017-0283-6

Liu, H., Howell, A. B., Zhang, D. J., and Khoo, C. (2019). A randomized, doubleblind, placebo-controlled pilot study to assess bacterial anti-adhesive activity in human urine following consumption of a cranberry supplement. Food Funt. 10, 7645-7652. doi: 10.1039/c9fo01198f

Liu, Y., Black, M. A., Caron, L., and Camesano, T. A. (2006). Role of cranberry juice on molecular-scale surface characteristics and adhesion behavior of Escherichia coli. Biotechnol. Bioeng. 93, 297-305. doi: 10.1002/bit.20675

Liu, Z., Ren, Z., Zhang, J., Chuang, C. C., Kandaswamy, E., Zhou, T., et al. (2018). Role of ROS and nutritional antioxidants in human diseases. Front. Physiol. 9:477. doi: 10.3389/fphys.2018.00477

Llobet, E., Tomás, J. M., and Bengoechea, J. A. (2008). Capsule polysaccharide is a bacterial decoy for antimicrobial peptides. Microbiol. Read. Engl. 154, 3877-3886. doi: 10.1099/mic.0.2008/022301-0

Lorenzo-Gómez, M. F., Padilla-Fernández, B., García-Cenador, M. B., VirsedaRodríguez, ÁJ., Martín-García, I., Sánchez-Escudero, A., et al. (2015). Comparison of sublingual therapeutic vaccine with antibiotics for the prophylaxis of recurrent urinary tract infections. Front. Cell. Infect. Microbiol. 5:50. doi: 10.3389/fcimb.2015.00050

Lorenzo-Gómez, M. F., Padilla-Fernández, B., García-Criado, F. J., Mirón-Canelo, J. A., Gil-Vicente, A., Nieto-Huertos, A., et al. (2013). Evaluation of a therapeutic vaccine for the prevention of recurrent urinary tract infections versus prophylactic treatment with antibiotics. Int. Urogynecology J. 24, 127134. doi: $10.1007 / \mathrm{s} 00192-012-1853-5$

Magasi, P., Pánovics, J., Illés, A., and Nagy, M. (1994). Uro-Vaxom and the management of recurrent urinary tract infection in adults: a randomized multicenter double-blind trial. Eur. Urol. 26, 137-140. doi: 10.1159/000475363

Mazarei, F., Jooyandeh, H., Noshad, M., and Hojjati, M. (2017). Polysaccharide of caper (Capparis spinosa L.) Leaf: extraction optimization, antioxidant potential, and antimicrobial activity. Int. J. Biol. Macromol. 95, 224-231. doi: 10.1016/j. ijbiomac.2016.11.049

McLellan, L. K., and Hunstad, D. A. (2016). Urinary tract infection: pathogenesis and outlook. Trends Mol. Med. 22, 946-957. doi: 10.1016/j.molmed.2016.09. 003

Melican, K., Sandoval, R. M., Kader, A., Josefsson, L., Tanner, G. A., Molitoris, B. A., et al. (2011). Uropathogenic Escherichia coli P and Type 1 fimbriae act in synergy in a living host to facilitate renal colonization leading to nephron obstruction. PLoS Pathog. 7:e1001298. doi: 10.1371/journal.ppat.1001298

Mendling, W. (2016). Vaginal microbiota. Adv. Exp. Med. Biol. 902, 83-93.

Meng, J., Zou, Z., and Lu, C. (2015). Identification and characterization of bioactive compounds targeting uropathogenic Escherichia coli from Sanjin tablets. J. Chem. 2015, 789809.

Mickymaray, S., and Al Aboody, M. S. (2019). In vitro antioxidant and bactericidal efficacy of 15 common spices: novel therapeutics for urinary tract infections? Medicina (Kaunas) 55:E289.

Mobley, H. L., and Hausinger, R. P. (1989). Microbial ureases: significance, regulation, and molecular characterization. Microbiol. Rev. 53, 85-108. doi: 10.1128/mmbr.53.1.85-108.1989 
Moore, M., Trill, J., Simpson, C., Webley, F., Radford, M., Stanton, L., et al. (2019). Uva-ursi extract and ibuprofen as alternative treatments for uncomplicated urinary tract infection in women (ATAFUTI): a factorial randomized trial. Clin. Microbiol. Infect. 25, 973-980. doi: 10.1016/j.cmi.2019.01.011

Morris, N. S., and Stickler, D. J. (1998). The effect of urease inhibitors on the encrustation of urethral catheters. Urol. Res. 26, 275-279. doi: 10.1007/ s002400050057

Muenzner, P., Tchoupa, A. K., Klauser, B., Brunner, T., Putze, J., Dobrindt, U., et al. (2016). Uropathogenic E. coli exploit CEA to promote colonization of the urogenital tract mucosa. PLoS Pathog. 12:e1005608. doi: 10.1371/journal.ppat. 1005608

Mulvey, M. A. (2002). Adhesion and entry of uropathogenic Escherichia coli. Cell. Microbiol. 4, 257-271. doi: 10.1046/j.1462-5822.2002.00193.x

Mulvey, M. A., Schilling, J. D., and Hultgren, S. J. (2001). Establishment of a persistent Escherichia coli reservoir during the acute phase of a bladder infection. Infect. Immun. 69, 4572-4579. doi: 10.1128/iai.69.7.4572-4579.2001

Munakata, K., Mochida, H., Kondo, S., and Suzuki, Y. (1980). Mutagenicity of $\mathrm{N}$-acylglycinohydroxamic acids and related compounds. J. Pharmacobiodyn. 3, 557-561. doi: 10.1248/bpb1978.3.557

Musher, D. M., Griffith, D. P., Yawn, D., and Rossen, R. D. (1975). Role of urease in pyelonephritis resulting from urinary tract infection with Proteus. J. Infect. Dis. 131, 177-181. doi: 10.1093/infdis/131.2.177

Ng, Q. X., Peters, C., Venkatanarayanan, N., Goh, Y. Y., Ho, C. Y. X., and Yeo, W.S. (2018). Use of Lactobacillus spp. to prevent recurrent urinary tract infections in females. Med. Hypotheses 114, 49-54. doi: 10.1016/j.mehy.2018.03.001

Noormandi, A., and Dabaghzadeh, F. (2015). Effects of green tea on Escherichia coli as a uropathogen. J. Tradit. Complement. Med. 5, 15-20. doi: 10.1016/j.jtcme. 2014.10.005

O’Brien, V. P., Hannan, T. J., Nielsen, H. V., and Hultgren, S. J. (2016). Drug and vaccine development for the treatment and prevention of urinary tract infections. Microbiol. Spectr. 4:10.1128/microbiolsec.UTI-0013-2012.

Ochoa-Brust, G. J., Fernández, A. R., Villanueva-Ruiz, G. J., Velasco, R., TrujilloHernández, B., and Vásquez, C. (2007). Daily intake of $100 \mathrm{mg}$ ascorbic acid as urinary tract infection prophylactic agent during pregnancy. Acta Obstet. Gynecol. Scand. 86, 783-787. doi: 10.1080/00016340701273189

O'Hanley, P., Lalonde, G., and Ji, G. (1991). Alpha-hemolysin contributes to the pathogenicity of piliated digalactoside-binding Escherichia coli in the kidney: efficacy of an alpha-hemolysin vaccine in preventing renal injury in the BALB/c mouse model of pyelonephritis. Infect. Immun. 59, 1153-1161. doi: 10.1128/iai. 59.3.1153-1161.1991

O'Hanley, P., Lark, D., Falkow, S., and Schoolnik, G. (1985). Molecular basis of Escherichia coli colonization of the upper urinary tract in BALB/c mice. J. Clin. Invest. 75, 347-360. doi: 10.1172/jci111707

Olczyk, P., Komosinska-Vassev, K., Wisowski, G., Mencner, L., Stojko, J., and Kozma, E. M. (2014). Propolis modulates fibronectin expression in the matrix of thermal injury. BioMed Res. Int. 2014:748101.

Pasupuleti, V. R., Sammugam, L., Ramesh, N., and Gan, S. H. (2017). Honey, propolis, and royal jelly: a comprehensive review of their biological actions and health benefits. Oxid. Med. Cell. Longev. 2017, 1-21. doi: 10.1155/2017/1259510

Paxman, J. J., Lo, A. W., Sullivan, M. J., Panjikar, S., Kuiper, M., Whitten, A. E., et al. (2019). Unique structural features of a bacterial autotransporter adhesin suggest mechanisms for interaction with host macromolecules. Nat. Comm. 10:1967.

Percival, S. L., Suleman, L., Vuotto, C., and Donelli, G. (2015). Healthcareassociated infections, medical devices and biofilms: risk, tolerance and control. J. Med. Microbiol. 64, 323-334. doi: 10.1099/jmm.0.000032

Pereira, E. M. R., da Silva, J. L. D. C., Silva, F. F., De Luca, M. P., Ferreira, E. F. E., Lorentz, T. C. M., et al. (2011). Clinical evidence of the efficacy of a mouthwash containing propolis for the control of plaque and gingivitis: a phase II study. Evid.-based complement. Altern. Med. 2011:750249.

Piatek, R., Zalewska-Piatek, B., Dzierzbicka, K., Makowiec, S., Pilipczuk, J., Szemiako, K., et al. (2013). Pilicides inhibit the FGL chaperone/usher assisted biogenesis of the Dr fimbrial polyadhesin from uropathogenic Escherichia coli. BMC Microbiol. 13:131. doi: 10.1186/1471-2180-13-131

Pinkner, J. S., Remaut, H., Buelens, F., Miller, E., Aberg, V., Pemberton, N., et al. (2006). Rationally designed small compounds inhibit pilus biogenesis in uropathogenic bacteria. Proc. Natl. Acad. Sci. U.S.A. 103, 17897-17902. doi: 10.1073/pnas.0606795103
Poggio, T. V., La Torre, J. L., and Scodeller, E. A. (2006). Intranasal immunization with a recombinant truncated FimH adhesin adjuvanted with CpG oligodeoxynucleotides protects mice against uropathogenic Escherichia coli challenge. Can. J. Microbiol. 52, 1093-1102. doi: 10.1139/w06-065

Poirier, C., Dinh, A., Salomon, J., Grall, N., Andremont, A., and Bernard, L. (2015). Antibiotic cycling prevents urinary tract infections in spinal cord injury patients and limits the emergence of multidrug resistant organism. J. Infect. 71, 491-493. doi: 10.1016/j.jinf.2015.06.001

Pope, A. J., Toseland, C. D., Rushant, B., Richardson, S., McVey, M., and Hills, J. (1998). Effect of potent urease inhibitor, fluorofamide, on Helicobacter sp. in vivo and in vitro. Dig. Dis. Sci. 43, 109-119.

Prasad, A., Cevallos, M. E., Riosa, S., Darouiche, R. O., and Trautner, B. W. (2009). A bacterial interference strategy for prevention of UTI in persons practicing intermittent catheterization. Spinal Cord. 47, 565-569. doi: 10.1038/sc.2008.166

Prattley, S., Geraghty, R., Moore, M., and Somani, B. K. (2020). Role of vaccines or recurrent urinary tract infections: a systematic review. Eur. Urol. Focus 6, 593-604. doi: 10.1016/j.euf.2019.11.002

Professionals, S.-O. (2019). EAU Guidelines: Urological Infections [Internet]. Uroweb [cité 2019 juill 9]. Available online at: https://uroweb.org/guideline/ urological-infections/ (accessed July 9, 2019).

Pu, X., Zhang, L. Y., and Zhang, J. H. (2016). A systemtic review of Sanjin tablets in the treatment of simple urinary tract infection: a randomized controlled trial. Lishizhen Med. Mat. Med. Res. 27, 1012-1014.

Rafsanjany, N., Senker, J., Brandt, S., Dobrindt, U., and Hensel, A. (2015). In vivo consumption of cranberry exerts ex Vivo antiadhesive activity against FimHdominated uropathogenic Escherichia coli: a combined in vivo, ex vivo, and in vitro study of an extract from Vaccinium macrocarpon. J. Agric. Food Chem. 63, 8804-8818. doi: 10.1021/acs.jafc.5b03030

Ramirez Sevilla, C., Gómez Lanza, E., Manzanera, J. L., Martin, J. A. R., and Sanz, M. A. B. (2019). Active immunoprophylacis with uromune ${ }^{\circledR}$ decreases the recurrence of urinary tract infections at three and six months after treatment without relevant secondary effects. BMC Infect. Dis. 19:901. doi: 10.1186/ s12879-019-4541-y

Ranfaing, J., Dunyach-Remy, C., Lavigne, J.-P., and Sotto, A. (2018a). Propolis potentiates the effect of cranberry (Vaccinium macrocarpon) in reducing the motility and the biofilm formation of uropathogenic Escherichia coli. PLoS One 13:e0202609. doi: 10.1371/journal.pone.0202609

Ranfaing, J., Dunyach-Remy, C., Louis, L., Lavigne, J.-P., and Sotto, A. (2018b). Propolis potentiates the effect of cranberry (Vaccinium macrocarpon) against the virulence of uropathogenic Escherichia coli. Sci. Rep. 8:10706.

Reygaert, W., and Jusufi, I. (2013). Green tea as an effective antimicrobial for urinary tract infections caused by Escherichia coli. Front. Microbiol. 4:162. doi: $10.3389 /$ fmicb.2013.00162

Riaz, S., Kashif Nawaz, S., and Hasnain, S. (2010). Bacteriocins produced by L. fermentum and L. acidophilus can inhibit cephalosporin resistant E. coli. Braz. J. Microbiol. 41, 643-648. doi: 10.1590/s1517-83822010000300015

Riegman, N., van Die, I., Leunissen, J., Hoekstra, W., and Bergmans, H. (1988). Biogenesis of F71 and F72 fimbriae of uropathogenic Escherichia coli: influence of the FsoF and FstFG proteins and localization of the Fso/FstE protein. Mol. Microbiol. 2, 73-80. doi: 10.1111/j.1365-2958.1988.tb00008.x

Roberts, I. S. (1995). Bacterial polysaccharides in sickness and in health. Microbiology 141, 2023-2031. doi: 10.1099/13500872-141-9-2023

Roberts, I. S. (1996). The biochemistry and genetics of capsular polysaccharide production in bacteria. Annu. Rev. Microbiol. 50, 285-315. doi: 10.1146/ annurev.micro.50.1.285

Roberts, J. A. (1991). Etiology and pathophysiology of pyelonephritis. Am. J. Kidney Dis. 17, 1-9. doi: 10.1016/s0272-6386(12)80242-3

Roberts, J. A., Kaack, M. B., Baskin, G., Chapman, M. R., Hunstad, D. A., Pinkner, J. S., et al. (2004). Antibody responses and protection from pyelonephritis following vaccination with purified Escherichia coli PapDG protein. J. Urol. 171, 1682-1685. doi: 10.1097/01.ju.0000116123.05160.43

Roberts, J. A., Kaack, M. B., Baskin, G., and Svenson, S. B. (1993). Prevention of renal scarring from pyelonephritis in nonhuman primates by vaccination with a synthetic Escherichia coli serotype O8 oligosaccharide-protein conjugate. Infect. Immun. 61, 5214-5218. doi: 10.1128/iai.61.12.5214-5218.1993

Rodríguez-Pérez, C., Quirantes-Piné, R., Uberos, J., Jiménez-Sánchez, C., Peña, A., and Segura-Carretero, A. (2016). Antibacterial activity of isolated phenolic 
compounds from cranberry (Vaccinium macrocarpon) against Escherichia coli. Food Funct. 7, 1564-1573. doi: 10.1039/c5fo01441g

Roos, V., Ulett, G. C., Schembri, M. A., and Klemm, P. (2006). The asymptomatic bacteriuria Escherichia coli strain 83972 outcompetes uropathogenic E. coli strains in human urine. Infect. Immun. 74, 615-624. doi: 10.1128/iai.74.1.615624.2006

Rosen, D. A., Hooton, T. M., Stamm, W. E., Humphrey, P. A., and Hultgren, S. J. (2007). Detection of intracellular bacterial communities in human urinary tract infection. PLoS Med. 4:e329. doi: 10.1371/journal.pmed.0040329

Saint, S., Meddings, J. A., Calfee, D., Kowalski, C. P., and Krein, S. L. (2009). Catheter-associated urinary tract infection and the medicare rule changes. Ann. Intern. Med. 150, 877-884.

Salomon, J., Denys, P., Merle, C., Chartier-Kastler, E., Perronne, C., Gaillard, J.-L., et al. (2006). Prevention of urinary tract infection in spinal cordinjured patients: safety and efficacy of a weekly oral cyclic antibiotic (WOCA) programme with a 2 year follow-up-an observational prospective study. J. Antimicrob. Chemother. 57, 784-788. doi: 10.1093/jac/dkl010

Sauer, F. G., Remaut, H., Hultgren, S. J., and Waksman, G. (2004). Fiber assembly by the chaperone-usher pathway. Biochim. Biophys. Acta. 1694, 259-267. doi: 10.1016/j.bbamcr.2004.02.010

Schaeffer, A. J., Jones, J. M., and Dunn, J. K. (1981). Association of in vitro Escherichia coli adherence to vaginal and buccal epithelial cells with susceptibility of women to recurrent urinary-tract infections. N. Engl. J. Med. 304, 1062-1066. doi: 10.1056/nejm198104303041802

Schulman, C. C., Corbusier, A., Michiels, H., and Taenzer, H. J. (1993). Oral immunotherapy of recurrent urinary tract infections: a double-blind placebocontrolled multicenter study. J. Urol. 150, 917-921. doi: 10.1016/s00225347(17)35648-3

Sharifi-Rad, J., Mnayer, D., Roointan, A., Shahri, F., Ayatollahi, S. A., Sharifi-Rad, M., et al. (2016). Antibacterial activities of essential oils from Iranian medicinal plants on extended-spectrum $\beta$-lactamase-producing Escherichia coli. Cell. Mol. Biol. 62, 75-82.

Shatzkes, K., Chae, R., Tang, C., Ramirez, G. C., Mukherjee, S., Tsenova, L., et al. (2015). Examining the safety of respiratory and intravenous inoculation of Bdellovibrio bacteriovorus and Micavibrio aeruginosavorus in a mouse model. Sci. Rep. 5:12899.

Silverman, J. A., Schreiber, H. L. IV, Hooton, T. M., and Hultgren, S. J. (2013). From physiology to pharmacy: developments in the pathogenesis and treatment of recurrent urinary tract infections. Curr. Urol. Rep. 14, 448-456. doi: 10.1007/ s11934-013-0354-5

Sobel, J. D. (1997). Pathogenesis of urinary tract infection. Role of host defenses. Infect. Dis. Clin. North Am. 11, 531-549.

Sockett, R. E. (2009). Predatory Lifestyle of Bdellovibrio bacteriovorus. Annu. Rev. Microbiol. 63, 523-539.

Soto, S. M., Smithson, A., Horcajada, J. P., Martinez, J. A., Mensa, J. P., and Vila, J. (2006). Implication of biofilm formation in the persistence of urinary tract infection caused by uropathogenic Escherichia coli. Clin. Microbiol. Infect. 12, 1034-1036. doi: 10.1111/j.1469-0691.2006.01543.x

Stapleton, A. E., Dziura, J., Hooton, T. M., Cox, M. E., Yarova-Yarovaya, Y., Chen, S., et al. (2012). Recurrent urinary tract infection and urinary Escherichia coli in women ingesting cranberry juice daily: a randomized controlled trial. Mayo Clin. Proc. 87, 143-150. doi: 10.1016/j.mayocp.2011.10.006

Stenutz, R., Weintraub, A., and Widmalm, G. (2006). The structures of Escherichia coli O-polysaccharide antigens. FEMS Microbiol. Rev. 30, 382-403.

Stolp, H., and Starr, M. P. (1963). Bdellovibrio bacteriovorus gen. et sp. n., a predatory, ectoparasitic, and bacteriolytic microorganism. Antonie Van Leeuwenhoek 29, 217-248. doi: 10.1007/bf02046064

Strömberg, N., Marklund, B. I., Lund, B., Ilver, D., Hamers, A., Gaastra, W., et al. (1990). Host-specificity of uropathogenic Escherichia coli depends on differences in binding specificity to Gal alpha $1-4 \mathrm{Gal}$-containing isoreceptors. EMBO J. 9, 2001-2010. doi: 10.1002/j.1460-2075.1990.tb08328.x

Suetens, C., Latour, K., Kärki, T., Ricchizzi, E., Kinross, P., Moro, M. L., et al. (2018). Prevalence of healthcare-associated infections, estimated incidence and composite antimicrobial resistance index in acute care hospitals and long-term care facilities: results from two European point prevalence surveys, 2016 to 2017. Euro Surveill. 23:1800516.

Sundén, F., Håkansson, L., Ljunggren, E., and Wullt, B. (2010). Escherichia coli 83972 bacteriuria protects against recurrent lower urinary tract infections in patients with incomplete bladder emptying. J. Urol. 184, 179-185. doi: 10.1016/ j.juro.2010.03.024

Sung, M. A., Fleming, K., Chen, H. A., and Matthews, S. (2001). The solution structure of PapGII from uropathogenic Escherichia coli and its recognition of glycolipid receptors. EMBO Rep. 2, 621-627. doi: 10.1093/embo-reports/ kve133

Svensson, A., Larsson, A., Emtenäs, H., Hedenström, M., Fex, T., Hultgren, S. J., et al. (2001). Design and evaluation of pilicides: potential novel antibacterial agents directed against uropathogenic Escherichia coli. Chembiochem 2, 915918. doi: 10.1002/1439-7633(20011203)2:12<915::aid-cbic915>3.0.co;2-m

Sybesma, W., Zbinden, R., Chanishvili, N., Kutateladze, M., Chkhotua, A., Ujmajuridze, A., et al. (2016). Bacteriophages as potential treatment for urinary tract infections. Front. Microbiol. 7:465. doi: 10.3389/fmicb.2016. 00465

Tammen, H. (1990). Immunobiotherapy with Uro-vaxom in recurrent urinary tract infection. The German urinary tract infection study group. Br. J. Urol. 65, 6-9. doi: 10.1111/j.1464-410x.1990.tb14649.x

Texier-Maugein, J., Clerc, M., Vekris, A., and Bebear, C. (1987). Ureaplasma urealyticum-induced bladder stones in rats and their prevention by flurofamide and doxycycline. Isr. J. Med. Sci. 23, 565-567.

Tong, Y., Wu, Q., Zhao, D., Liu, Y., Cao, M., Zhang, L., et al. (2011). Effects of Chinese herbs on the hemagglutination and adhesion of Escherichia coli strain in vitro. Afr. J. Tradit. Complement. Altern. Med. 8, 82-87.

Torella, M., Del Deo, F., Grimaldi, A., Iervolino, S. A., Pezzella, M., Tammaro, C., et al. (2016). Efficacy of an orally administered combination of hyaluronic acid, chondroitin sulfate, curcumin and quercetin for the prevention of recurrent urinary tract infections in postmenopausal women. Eur. J. Obstet. Gynecol. Reprod. Biol. 207, 125-128. doi: 10.1016/j.ejogrb.2016. 10.018

Trautner, B. W., Hull, R. A., Thornby, J. I., and Darouiche, R. O. (2007). Coating urinary catheters with an avirulent strain of Escherichia coli as a means to establish asymptomatic colonization. Infect. Control Hosp. Epidemiol. 28, 92-94. doi: $10.1086 / 510872$

Uehling, D. T., Hopkins, W. J., Balish, E., Xing, Y., and Heisey, D. M. (1997). Vaginal mucosal immunization for recurrent urinary tract infection: phase II clinical trial. J. Urol. 157, 2049-2052. doi: 10.1097/00005392-199706000-00004

Uehling, D. T., Hopkins, W. J., Elkahwaji, J. E., Schmidt, D. M., and Leverson, G. E. (2003). Phase 2 clinical trial of a vaginal mucosal vaccine for urinary tract infections. J. Urol. 170, 867-869. doi: 10.1097/01.ju.0000075094.54767.6e

Ujmajuridze, A., Chanishvili, N., Goderdzishvili, M., Leitner, L., Mehnert, U., Chkhotua, A., et al. (2018). Adapted bacteriophages for treating urinary tract infections. Front. Microbiol. 9:1832. doi: 10.3389/fmicb.2018.01832

Ulrey, R. K., Barksdale, S. M., Zhou, W., and van Hoek, M. L. (2014). Cranberry proanthocyanidins have anti-biofilm properties against Pseudomonas aeruginosa. BMC Complement. Altern. Med. 14:499. doi: $10.1186 / 1472-6882-14-499$

Varki, A. (2008). Sialic acids in human health and disease. Trends Mol. Med. 14, 351-360. doi: 10.1016/j.molmed.2008.06.002

Wagenlehner, F. M. E., Ballarini, S., Pilatz, A., Weidner, W., Lehr, L., and Naber, K. G. (2015). A randomized, double-blind, parallel-group, multicenter clinical study of Escherichia coli-Lyophilized lysate for the prophylaxis of recurrent uncomplicated urinary tract infections. Urol. Int. 95, 167-176. doi: 10.1159/ 000371894

Wizemann, T. M., Adamou, J. E., and Langermann, S. (1999). Adhesins as targets for vaccine development. Emerg. Infect. Dis. 5, 395-403. doi: 10.3201/eid0503. 990310

Wojnicz, D., Tichaczek-Goska, D., Korzekwa, K., Kicia, M., and Hendrich, A. B. (2016). Study of the impact of cranberry extract on the virulence factors and biofilm formation by Enterococcus faecalis strains isolated from urinary tract infections. Int. J. Food Sci. Nutr. 67, 1005-1016. doi: 10.1080/09637486.2016. 1211996

Xu, W., Flores-Mireles, A. L., Cusumano, Z. T., Takagi, E., Hultgren, S. J., and Caparon, M. G. (2017). Host and bacterial proteases influence biofilm formation and virulence in a murine model of enterococcal catheter-associated urinary tract infection. NPJ Biofilms Microbiomes. 3:28.

Yang, B., and Foley, S. (2018). First experience in the UK of treating women with recurrent urinary tract infections with the bacterial vaccine Uromune ${ }^{\circledR}$. BJU Int. 121, 289-292. doi: 10.1111/bju.14067 
Yang, B., and Foley, S. (2019). Urinary tract infection vaccines - the 'burning' issue. BJU Int. 123, 743-744. doi: 10.1111/bju. 14678

Zaborska, W., Kot, M., and Superata, K. (2002). Inhibition of jack bean urease by 1,4-benzoquinone and 2,5-dimethyl-1,4-benzoquinone. Evaluation of the inhibition mechanism. J. Enzyme Inhib. Med. Chem. 17, 247-253. doi: 10.1080/ 1475636021000011670

Zhao, K., Liu, B., Wei, W., Ma, Q., Zhao, W., and Zhang, S. (2011). Clinical study of clearing liver fire, removing dampness, strengthening spleen and tonifying kidney methods in treating middle-aged and old woman with chronic urinary tract infection. Int. J. Tradit. Chin. Med. 33, 976-978.
Conflict of Interest: The authors declare that the research was conducted in the absence of any commercial or financial relationships that could be construed as a potential conflict of interest.

Copyright (๑) 2020 Loubet, Ranfaing, Dinh, Dunyach-Remy, Bernard, Bruyère, Lavigne and Sotto. This is an open-access article distributed under the terms of the Creative Commons Attribution License (CC BY). The use, distribution or reproduction in other forums is permitted, provided the original author(s) and the copyright owner(s) are credited and that the original publication in this journal is cited, in accordance with accepted academic practice. No use, distribution or reproduction is permitted which does not comply with these terms. 